\title{
Tanzimat Döneminde Açılan Yeni Okullarda Arapça Öğretiminde Kullanılan Ders Kitaplarının Yöntem Açısından İncelenmesi
}

\section{The Examination Of The Course Books Used In Arabic Teaching In New Schools Opened During The Tanzimat Era In Terms Of Method}

\author{
Kerim $\mathrm{AÇIK}^{1}$ (])
}

IIstanbul 29 Mayıs Üniversitesi, Eğitim Fakültesi, Arapça Öğretmenliği Bölümü, İstanbul, Türkiye

\section{ORCID: K.A. 0000-0001- 6671-2359}

Sorumlu yazar/Corresponding author: Kerim AÇIK (Doç. Dr.),

İstanbul 29 Mayıs Üniversitesi, Eğitim Fakültesi, Arapça Öğretmenliği Bölümü, İstanbul, Türkiye E-posta:kerimacik111@hotmail.com

Başvuru/Submitted: 15.10 .2020 Revizyon Talebi/Revision Requested: 05.10.2020

Son Revizyon/Last Revision Received: 28.10.2020

Kabul/Accepted: 28.10 .2020

Atıf/Citation: Acik, Kerim. "Tanzimat Döneminde Açılan Yeni Okullarda Arapça Öğretiminde Kullanılan Ders Kitaplarının Yöntem Açısından İncelenmesi". Şarkiyat Mecmuası Journal of Oriental Studies 37 (2020), 1-49. https://doi.org/10.26650/jos.2020.006 öz

Osmanlı Devleti'nde eğitim alanında, Tanzimat dönemine gelinceye kadar üç önemli öğretim kurumu bulunmaktaydı. İlköğretim basamağı olarak sıbyan mektepleri, orta ve yüksek öğretim kurumunu oluşturan medreseler ile Devlet'in yönetim kadrolarını yetiştirmek amacıyla kurulan özel okul niteliğindeki Enderun Mektebi'dir. Bu okullarında Arapça öğretim yöntemi olarak; takrîr, ezber, kavrama, imlâ, tekrar, soru-cevap, müzâkere ve münâzara yöntemleri kullanılmaktaydı. Tanzimat Dönemi'nde başlatılan yenileşme hareketi kapsamda eğitim alanındaki en önemli hamle okullaşmadır. Teşkilatlanmaya önem verilerek birçok yeni okul açılmıştır. Bu okullarda, “Usül-i Cedid (yeni usül)” eğitimin gereği olarak, okul müfredatında yer alan derslerin belirlenen saat sayısına uygun haftalık programları yapılmış ve yeni öğretim yöntemi uygulanmıştır. Yeni Arapça ders kitapları yazılarak okullarda uygulanmaya başlanmıştır. Tanzimat Dönemi'nde Arapça sarf-nahiv kitapları hazırlarken dört metot izlenmiştir: 1- Klasik Arapça Öğretim Kitaplarını Yeniden Düzenleme Yöntemi: Medreselerde Arapça öğretiminde kullanılan klasik eserlerin öğretimini kolaylaştırmak amacıyla "yeni yönteme" uygun olarak hazırlanan kitaplardır. 2-Avrupa'da Ortaya Çıkan Dil Öğretim Yöntemlerini Arapçaya Uyarlama Yöntemi: Avrupa'da ortaya çıkan dil öğretim yöntemleri prensipleri Arapça öğretimi kitaplarına uyarlanmıştır. 3- Muhtelit (Eclectic) Yöntem: Avrupa'da ortaya çıkan yeni yöntemlerle birlikte hem klasik ders kitapları hem de Tanzimat Döneminde hazırlanmış diğer eserler incelenmiş, bilgiler harmanlanarak "muhtelit" usulde kitaplar hazırlanmıştır. 4-Tanzimat Dönemi Dilcileri Tarafından Geliştirilen Yeni Yöntemler: Türk dilcilerinin kendilerine has Arapça öğretimine dair tecrübe ve düşüncelerinin bir sonucu olarak "Arap Dilini kolay öğretme" prensibini ön planda tutarak hazırladıkları özgün eserlerdir. Tanzimat Dönemi'nde Arapça eğitimde yeni metot arayışları, alimler tarafından hazırlanan öğretim kitaplarına yansımış ve birçok kitap telif edilmiştir. Arapçanın öğretiminde özgün yöntemler geliştirilmiştir. Bu makalede; Arapça öğretmek üzere hazırlanan bazı eserler incelenerek metot bakımından analizleri yapılacaktır.

Anahtar kelimeler: Arapça Öğretimi, Tanzimat Eğitim, Arapça Öğretim Yöntemi, Tanzimat Dönemi Arapça Ders Kitapları 


\begin{abstract}
Three important teaching institutions in the Ottoman Empire until the Tanzimat Era were sıbyan schools, the madrasas and Enderun Schools. Different methods of teaching Arabic were used in these schools like memorization, comprehension, spelling, repetition, $Q \& A$, negotiation and discussion. The most important development regarding the innovation moves during the Tanzimat Era was schooling. In these schools, as a requirement of the new system, weekly plans were made and switched to the application of the teaching method called "new method" in schools. Linguists followed four methods while preparing grammer books: 1-Rearranging Classical Arabic Teaching Books: Authors have prepared new coursebooks in accordance with "new method" to simplify the classical works. 2- Adapting Language Teaching Methods Emerging in Europe to Arabic: Authors adapted the recent principles of language teaching methods to Arabic teaching. 3- Eclectic Method: By examining all works prepared during Tanzimat Period, along with books of the new methods emerging in Europe books were written in an eclectic manner. 4- Methods Developed by the Tanzimat Period Linguists: Turkish linguists in their own way of teaching Arabic prepared works in which the principle of "simplifying Arabic language" was prioritized. The searches for a new method for Arabic teaching during this period was reflected in the teaching books prepared by many scholars and many books were written. Thus, teaching methods that can be considered authentic have been developed in the teaching of Arabic as a foreign language. In this article, certain works prepared to teach Arabic will be examined and analysed in terms of method.
\end{abstract}

Keywords: Arabic Language Teaching, Education in Tanzimat Reform Era, Arabic Teaching Methods, Tanzimat Reform Era Arabic Course Books

\title{
EXTENDED ABSTRACT
}

There were three important teaching institutions in the field of education in the Ottoman Empire until the Tanzimat Era. Children aged 5-6 were taken to sibyan schools for primary education. In these primary school-level schools, the Koran reading, writing, catechism, and a'mâl-i erbâ'a (numerate) were taught. Beginner level Arabic morphology was also taught in some sibyan schools.

The madrasas made up the secondary and higher education after the sibyan schools in Ottoman education system. The teaching activities that began in the XI. century with Nizamiye madrasas established during the Seljuk period to cultivate fiqh scholars was continued during the Anatolian Seljuks and Ottomans in madrasas. The deterioration in the administrative system of madrasas over time was reflected in the education and this process continued until the Tanzimat Era. There is no article related to the reform of madrasas and sibyan schools in Imperial Edict of Reorganization. For this reason, madrasas were unable to keep up with the modernization efforts quickly and adequately that begin with Tanzimat. So much so that the first serious innovation efforts were only carried out during the II. Legitimacy.

As morphology books el-Emsile, el-Binâ, el-Maksûd, el-İzzî, el-Merâh and eş-Şâfiye', two el-Avâmil (Avâmil-i Cürcanî ve Avâmil-i Birgivî), İzhâru'l-Esrâr, el-Kâfiye and el-Kâfiye's Molla Câmi Şerhi of Nahiv books widely used in the classical period were used in madrasas.

In Ottoman Madrasas, there was a promotion system based on obtaining the right to read books from the next level after finishing the basic and auxiliary books of one level in an order called "passing books". Accordingly, the duration of the education in madrasas at all levels could be extended or shortened depending on the student's effort and capacity. As 
Arabic teaching methods report, memorization, comprehension, spelling, repetition, Q\&A, negotiation and discussion were used.

Enderun School is the third important teaching institution of the Ottoman period. It is a private school established to train the state's administrative staffs and operates within the palace. Courses such as the Kuran, hadith, kalam, calligraphy, Arabic, Persian, eloquence, poetry, philosophy, history, mathematics, and geography were taught in Enderun School. The difference between the teaching method applied in madrasas and Enderun School is the practical training that students had gotten in military and administrative subjects. In this respect, the school had a special education system where a wide variety of arts, administrative, political, and military knowledge were taught with practice and students could reach high levels according to their abilities.

\section{New Schools Opened After the Announcement of the Edict of Reorganization and Arabic Teaching}

The innovation (modernization) moves initiated in all areas during the Tanzimat Era led to many positive developments in social and cultural areas. In this context, the most important activity that stands out in the field of education is schooling. New schools established at different levels and various fields were tried to be expanded all over the country by paying attention to the organization in the field of education. The primary and secondary education steps of the new education system were established as Rüşdiye, İdadi, and Sultan Schools which had been opening since 1840 and in 1900 with the opening of Daru'l-fünun, the higher education step was also established. In addition to these schools, which constitute the basis of the education system, many schools in vocational areas had been opened by the state. Additionally, with the permission of private enterprise initiatives, private schools were opened at rüşdiye, idadi and Sultani levels. Almost in all of these schools, Arabic was taught both in order to help Ottoman Turkish and as a foreign language. This article will focus on Arabic teaching in major schools.

\section{Arabic Teaching in Rüşdiye Schools}

The first of method searching was carried out by Kemal Efendi, Director of Mekâtib-i Umumiye in 1264/1847. A rüşdiye school opened in Davutpaşa and a four-year program was implemented with one-year preparatory class in this school, and one year preparatory in Dâru'lfunûn. Arabic teaching in this school was based on Usûl-i Cedid. At that time, the following information was in the sources about Usûl-i Cedid and Arabic teaching.

"With this new method, rüşdiye students have been started in Arabic and Persian with clear and easy expressions at a level their perception can accept. At the end of the teaching, the student completed the entire morphology of Arabic and the book of Avamil. Now, they have begun ti translate their Arabic lessons." 
The following statement in the sources about the teaching of the mentioned books is essential in terms of the reached level and results:

"In 1265/1848, about twenty children Rüşdiyes were tested in front of the Meclis-i Maârif. These children are only eight years old. even though they had not read anything other than Emsile and Bina in Arabic, and the two small tractates in Persian, they answered the questions nicely, and have shown that they have gained a high degree of knowledge in three years with great effort and study."

\section{Arabic Teaching in İdadi Schools}

The schools referred to as İdadî, were first opened in 1261/1845 in military centres to cover the lack of information for those who wanted to enter military schools. The term İdadî was accepted as the name of the secondary education institution in 1286/1869 with Maârif-i Umumiye Regulation. With this regulation, an İdadî would be opened in every thousand-digit town. İdadî schools were planned as a three-year continuum school after four-year rüşdiyes. Although Arabic lessons were not initially considered in their programs, Arabic lessons had been held since 1869 .

Usul-i Cedid was applied as the Arabic teaching method. In addition to some classic works, books prepared to implement in newly opened schools with special methods were also used in Arabic teaching in İdadîs.

\section{Arabic Teaching in Sultanî Schools}

Sultanîs were the schools opened in accordance with Usul-i Cedid education, in order to raise people who know all kinds of language and sciences, to enable every class to educate themselves, to conduce to the combining of elements living in the Ottoman Empire.

In the curriculum between 1316/1898 and1317/1999, Arabic lessons are as follows:

"Sunuf-1 İptidaiye (Three Years): No Arabic lesson.

$\begin{array}{ll}\text { Sunuf-1 Tâliye } & \text { Sunuf-1 Âliye } \\ \text { 1st Grade: Arabî } & \text { 4th Grade: Arabî } \\ \text { 2nd Grade: Arabî } & \text { 5th Grade: Arabî and Eloquence } \\ \text { 3rd Grade: Arabî } & \text { 6th Grade Arabî and Eloquence" }\end{array}$

The search for methods to simplify language teaching was ongoing in Mekteb-i Sultanî as in İdadis. For instance, the course minister Cemil Bey's book Sarf-1 Arabî which was taught in Müptedi classes aimed to teach the student Arabic morphology easily. It was also possible to evaluate the works el-Muntehab and el-Muktedab which Mehmed Zihni Efendi prepared in order to teach the Arabic grammar easily, as important examples of method searches during this period. 


\section{Arabic Teaching in Private Schools}

The best example of Arabic teaching in private schools is the private school opened by Hacı İbrahim Efendi in Fatih, İstanbul on December 4, 1883 (1301) and called "Dâru't-Talim". Dâru't-talim was a private school with iptidai and rüşdiye.

According to Hac1 Ibrahim Efendi, the flaw in the current teaching system was in the method and language teaching should have been done as it did in Europe. According to him, first Arabic which shares the rules of our language should be learnt and then French and even Greek and Armenian. İbrahim Efendi found a minimum of two years necessary to teach Arabic fully. He stated the rules of the method he applied in Arabic teaching as follows: During the specified time for teaching Arabic, "students should be kept in a boarding school and should not be taught any other course and should focus on only to Arabic. The teaching of the other courses should be taught in Arabic after reaching a certain level. He stated the objectives of teaching Arabic as follows:

“...providing the student with the ability to decipher and translate Arabic expressions especially what they read on Arabic newspapers within two, three years of strict instruction of Arabic language."

These goals had been reached and the students of the school had successfully passed the test in the presence of the Sultan.

In these newly opened schools, as a requirement of the new system, weekly plans/programs were made in accordance with the hours of courses in the school curriculum and switched to the application of the teaching method called "Usül-i Cedid (new method)" in schools. Accordingly, Arabic teaching books in accordance with the new system and teaching method had been started to be written and applied in schools. The most important feature of the move to prepare books in accordance with the approach of innovation in Arabic teaching during the Tanzimat Era is the search for a new teaching method by authors. Thus, teaching methods that can be considered authentic were developed in the teaching of Arabic as a foreign language. In this article, certain works prepared to teach Arabic will be examined and analysed in terms of method. During the Tanzimat Era, the linguists followed four different methods while preparing grammar/morphology-based coursebooks:

1. Authors prepared new coursebooks in accordance with "new method" in order to simplify the teaching of classical works such as Emsile, Bina, Maksud, Avamil, İzhar, which used in Arabic Teaching in madrasas.

Example: A. Cevdet Hocazâde, Arapça Yeni Sarf ve Nahiv (Second Part), İstanbul, Mekteb-i Harbiye Publishing, 1323.

2. Authors prepared new coursebooks by adapting the recent principles of language teaching methods that had emerged in Europe to the objectives of teaching Arabic in Ottoman State schools.

Example: Literature Teacher of Galata Sultanî Ali Suad, founder of el-Hedaya Magazine and newspaper owner of el-Hilal el-Osmani Abdülaziz Caviş, Arabic Teacher of İstanbul 
Sultanî Edhemzade Muhammed Kemaleddin, Ta'limu'l-Lugati'l-Arabîye a'lâ Tarîkat-1 Berlitz, İstanbul, Mahmud Bey Publishing, 1331.

3. Authors examined both classical textbooks and other works prepared during Tanzimat Era, along with books of the new methods emerging in Europe and they blended this information and wrote books in an eclectic manner, as they call it.

Example: Mustafa Cemil - Ahmed Naim, Mekteb-i Sultanîye Mahsus Sarf-1 Arabî and Temrînât, İstanbul: Mahmud Bey Publishing, 1323

4. As a result of the experience and thoughts of Turkish linguists in their own teaching Arabic, these authentic works are the works that had been prepared by prioritizing the principle of "simplifying the teaching of Arabic language.

Example: Süleyman Tevfik from Mehmed Safâ, Gayetu'l-ereb fi Teallüm-i Lisani'l-Arab, İstanbul, el-'Adl Publishing, 1331 (1913)

As a result, in the period from Tanzimat to the Republic, the heated debate sparked by the teaching of Arabic and the new ideas raised were not in vain and reflected in the books prepared by many valuable language scholars as new teaching methods and applied in many schools. Many Arabic experts who adopted this innovative approach had been trained, proving that Arabic can be taught more easily and effectively with New Method. The works of these linguists should be considered as authentic method studies in the field of Foreign Language Teaching, and language-teaching methodists who work in this field should be shown respect and value. It should also be noted that the studies carried out during the Tanzimat Era contributed positively to the field of Arabic teaching. 


\section{Giriş}

Tanzimat dönemine gelinceye kadar Osmanlılarda maârif alanında üç önemli öğretim kurumu mevcuttur. İlköğretim basamağı olarak sıbyan mektepleri, orta ve yüksek seviyeli öğretim kurumu olarak da medreseler kurulmuştur. Osmanlı Devleti'nin yönetim kadrolarının yetiştirilmesi amacıyla kurulan Enderun Mektebi ise saray içinde faaliyet gösteren özel bir okuldu.

Osmanlılarda ilkokul olarak sıbyan (=çocuklar) mektepleri vardı. Genellikle camilerin yanında yer alan bu okullara 5-6 yaşlarına ulaşmış çocuklar alınırdı. Çocuklar özel törenler düzenlenerek bu okullara başlarlardı. ${ }^{1}$ Hemen hemen her mahallede açılan sıbyan mektepleri vakıf sistemiyle kurulur ve vakfiyede belirtilen çalışma prensiplerine göre eğitim öğretim faaliyetlerini yürütürdü. Her okulun programı, kendi vakfiyesinde belirtilmesine rağmen uygulanan eğitimin pek çok ortak yönü vardı. ${ }^{2}$ İlkokul seviyesindeki bu okullarda Kur'an okuma, yazı yazma, ilmihal ve a'mâl-i erbâ'a (dört işlem) öğretilirdi. ${ }^{3}$ Bazı sıbyan mekteplerinde başlangıç seviyesinde Arapça sarf öğretimi yapılırdı. ${ }^{4}$ Sıbyan mekteplerinde öğretim dili Türkçedir. ${ }^{5}$ Özellikle bu okulların ilk okul seviyesinde olduğu düşünülürse bu görüş akla yatkın gelmektedir. Çünkü bu okullarda öğretimin esas hedefi öğrencinin Kur'an-1 Kerim'i yüzünden doğru okuması ve bir ileri adım olarak ezberleme aşamasına hazırlanmasıdır.

Osmanlı eğitim sisteminde sıbyan mekteplerinden sonra orta ve yüksek öğretimin yapıldığı medreseler yer almaktadır. XI. yüzyılda Selçuklular döneminde, fikıh alimleri yetiştirmek amacıyla kurulan Nizamiye Medreseleri ${ }^{6}$ Anadolu Selçukluları ve Osmanlılar döneminde de varlı̆̆ını sürdürmüştür. Osmanlılarda ilk medrese, 731/1330'da İznik'te açılmış ${ }^{7}$ daha sonra devletin sınırlarının genişlemesine bağlı olarak ülkenin her tarafına yayılmıştır. Osmanlı eğitim ve öğretim sisteminin temelini oluşturan medreseler, cami ve hastaneler gibi vakıf hizmeti kapsamında varlıklı kimseler tarafindan kurulmuşlardır. ${ }^{8}$

Başlangıçta Selçuklu Dönemindeki eğitim sistemin takip edildiği Osmanlı medreselerinde, 9 ilk köklü değişim Fatih Sultan Mehmed döneminde olmuştur. Fatih, kurmuş olduğu caminin doğu ve batı taraflarına toplam sekiz adet medrese yaptırmış̦tır. Sahn-1 Semân ve Medâris-i Semâniye adı verilen medreselerin programları dönemin ileri gelen alimleri tarafindan oluşturulmuştur. ${ }^{10}$

1 A. Turan Arslan, "XVI. Osmanlı İlmi Hayatına Genel Bir Bakış", Osmanlı VIII, Ed. Güler Ercan, Ankara: Yeni Türkiye Yayınları, 1999, s.43.

2 Ekmeleddin İhsanoğlu, "Osmanlı Eğitim ve Bilim Kurumları", Osmanlı Devleti ve Medeniyeti Tarihi, Ed. Ekmeleddin İhsanoğlu, c. II, (s.a.:223-359), İstanbul: İslam Tarihi, Sanat ve Kültür Araştırma Merkezi (IRCICA) 1998, s.231.

3 Bayram Kodaman, Abdülhamit Devri Eğitim Sistemi, Ankara 1991, s.57.

4 M.Şakir Ülkütaşır, "Sıbyan Mektepleri”, Türk Kültürü, sy. 33/Temmuz, Ankara 1965, 595; A. Turan Arslan, "XVI. Osmanlı İlmi Hayatına Genel Bir Bakış", s.43.

5 İhsanoğlu, a.g.e., s.231.

6 İhsanoğlu, a.g.e., s.232.

7 İsmail Hakkı Uzunçarşı1l, Osmanlı Devleti'nin İlmiye Teşkilatı, Ankara 1988, s.1.

8 İhsanoğlu, a.g.e., s.232.

9 Yusuf Halaçoğlu, XIV-XVII. Yüzyıllarda Devlet Teşkilatı ve Sosyal Yapı, Ankara 1995, s.130.

10 Uzunçarş11, a.g.e., s.7. 
Yine bu dönemde medreseler, okutulan kitaplar ve hocaların aldığg maaşlara göre bir tertibe tabi tutularak ${ }^{11}$ hiyerarşik bir yapıya kavuşturulmuştur.

Osmanlı medreselerinde ikinci büyük değişim, Kanuni Sultan Süleyman zamanında olmuştur. Kanunî, Osmanlı kültür, bilim ve eğitim tarihinde seçkin bir konuma sahip olan Süleymaniye Külliyesini kurmuştur (967/1559). ${ }^{12}$ İçerisinde Dârulhadis, Dâruttıp, 4 adet genel medrese, bir Sıbyan mektebi, kütüphâne, eczane, Dâruşşifa, hamam ve misafirhâne yer alıyordu. ${ }^{13} \mathrm{Bu}$ külliye, Fatih Külliyesinden sonra dini, sağlık, sosyal ve kültürel hizmetlerin bir bütün olarak yürütüldüğü Osmanlı Külliyelerinin en gelişmiş örneğini teşkil etmiştir.

Kanunî devrinde en yüksek seviyeye ulaşan medreseler, XVI. yüzyılın ortalarından itibaren devletin diğer kurumları gibi çeşitli yönlerden gerilemeye başlamış, sahip olduğu idari ve akademik yeterlilikleri muhafaza edememiştir. ${ }^{14}$ Medreselerin idari sisteminde başlayan bozulma eğitim öğretime de yansımış ve bu süreç Tanzimat dönemine kadar devam etmiştir. Tanzimat fermanında, medreseler ve sıbyan mekteplerinde reform yapılmasıly ilgili bir madde yoktur. ${ }^{15} \mathrm{Bu}$ nedenle Medreseler, Tanzimat'la başlayan modernleşme gayretlerine hızlı ve yeterli bir şekilde ayak uyduramamıştır. Öyle ki ilk ciddi yenileşme çabaları ancak II. Meşrutiyet döneminde gerçekleştirilebilmiştir. ${ }^{16}$ 1326/1908' de başlayan II. Meşrutiyet dönemi medreselerin çok önemli değişikliklere uğradığı dönemdir. Bu dönemde genel medreseler yanında bazı ihtisas medreseleri de açılmıştır. Bu medreselerde imam-hatip, müezzin ve vaizleri yetiştirilmesi amaçlanmaktayd1. ${ }^{17}$

Osmanlı eğitim teşkilatı içinde önemli öğretim kurumlarından biri de, Enderun Mektebi adıyla bilinen okuldur. Burası Osmanlı İmparatorluğu'nun idari yapısında görev alacak seçkin elemanların yetiştirildiği Topkapı Sarayı içinde yer alan bir okul idi. ${ }^{18}$ Hıristiyan ailelerden gönüllülük usulüne göre toplanan küçük çocuklar, önce Müslüman Türk ailelerin yanında yetiştirilir sonra, acemi oğlanlar saray ve kışlalarında eğitim görürlerdi. Buralardaki eğitimlerinin ardından "çıkma” adı verilen dağıtıma tabi tutularak çeşitli askeri zümreler içerisine gönderilirlerdi. Bu zümrelerde kabiliyet ve üstün yeteneklerini gösterenler, daha yüksek seviyede eğitilmek üzere Enderun'a alınırdı. Enderun mektebi bu yapısıyla imparatorluğun sonuna kadar devletin idari kadrolarını oluşturan elit tabakanın büyük bir kısmının yetiştiği bir okul

11 İlhan Tekeli ve Selim İlkin, Osmanlı İmparatorluğu’nda Eğitim ve Bilgi Üretim Sisteminin Oluşumu ve Dönüşümü, Ankara: Türk Tarih Kurumu, 1993, s. 64.

12 İhsanoğlu, a.g.e., s.240.

13 Uzunçarş1lı, a.g.e., s.33; Yahya Akyüz, Türkiye Eğitim Tarihi, İstanbul 1994, s. 58-59; İhsanoğlu, a.g.e., s.240241.

14 İhsanoğlu, a.g.e., s.232; Akyüz, a.g.e., s.67; Geniş bilgi için bkz. İsmail Hakkı Baykal, Enderun Mektebi Tarihi, İstanbul, t.y.

15 Şerafettin Yaltkaya, “Tanzimattan Evvel ve Sonra Medreseler”, Tanzimat I: Yüzüncü Yıldönümü Münasebetiyle, Ankara: Maarif Vekâleti, 1940, s.466.

16 Nesimi Yazıcı, "II. Meşrutiyette Din Görevlisi Yetiştiren Kurumlar Üzerine Bazı Gözlemler”, M.E.B. Din Ögretimi Dergisi, sy. 36/Eylül-Ekim, Ankara 1992, s.30-31.

17 Kerim Açık, Tanzimate tan Cumhuriyete Arapça Öğretimi (Kaynaklar ve Yöntemler), Yayımlanmamış Doktora Tezi, Marmara Üniversitesi Sosyal Bilimler Enstitüsü, İstanbul 2002, s.46.

18 İhsanoğlu, a.g.e., s.251; A. Turan Arslan, "XVI. Osmanlı İlmi Hayatına Genel Bir Bakış”, s. 45. 
olmuştur. XIX. yüzyıl başlarına kadar köklü bir değişikliğe uğramadan varlığını sürdürmüştür. ${ }^{19}$

Enderun Mektebinde Kur'an-1 Kerim, hadis, kelam, hat, Arapça, Farsça, belagat, şiir, felsefe, tarih, riyaziye, coğrafya gibi dersler okutulmuştur. ${ }^{20}$ Enderun Mektebi'nde sözü geçen derslerin yanı sıra çeşitli sanatların, idarî ve siyasî bilgilerin uygulamalı olarak öğretildiği ve öğrencilerin kabiliyetlerine göre yüksek seviyelere ulaşabildiği özel bir eğitim sistemi vardı. ${ }^{21}$

\section{Tanzimat'a Kadar Olan Dönemde Arapça Öğretimi ve Yöntemi}

\subsection{Sıbyan Mekteplerinde Öğretim Yöntemleri}

Sıbyan mekteplerinde klasik dönemde öğretimin temel hedefi yanlışsız Kur'ân okumaktı. Kur'ân'ın anlamı açıklanmadan yalnızca okunuşu öğretilirdi. ${ }^{22}$ Kur'ân öğretimi metodik olarak değerlendirildiğinde; "önemli olan anlamlı öğrenme değil fakat öğretilen bilgileri ezber yoluyla kazanma yeteneğinin geliştirilmesi” usulünün tatbik edildiği söylenebilir. Sibyan mekteplerinde çocuklara teorik bilgiler öğretilmemekte fakat, hafizalarının geliştirilmesi ön planda tutulmakta idi. Kitap sayısının az olduğu Tanzimat'tan önceki devirde Kur'ân ve dua kitapları, öğretmenlerin elinde bu usulün uygulanması için en uygun araçtı. ${ }^{23}$ Sıbyan mekteplerinde öğretim dili Türkçe idi. Arapça öğretimi söz konusu olmadığı için, bir yöntemden söz etmek oldukça güçtür. Öğretim usulü; her yeni konunun ezberlenmesine ve öğretmenin önünde hatasız şeklide tekrar edilmesine dayanmaktaydı. Her çocuk, hocanın önüne gider, dersini okur, yerine döner ve dersi ezberleyebilmek için birçok kez tekrar ederdi. Bu bireysel ve her çocuğun düzeyine uygun bir yöntem idi. ${ }^{24}$ Muallim Mehmet Efendi yazmış olduğu Nevhatü'l-uşşak adlı şiirde (XVII. Yüzyıl) bir sıbyan mektebinin hem günlük ders programını, hem de tatbik olunan öğretim usulünün genel çizgilerini şu şekilde kaydetmiştir: ${ }^{25}$

"Otururdu üç tertip üzere sıbyan

Kimi hece okurdu kimi Kur'an

Önümde herbiri tekrar ederdi

Alup dersini yerine giderdi"

Aynı dersi tekrarlayan çocuklar bazen bir koro halinde yüksek sesle derslerini tekrar ederdi. Bu durum aynı zamanda öğrencilerin akranlarının yardımıyla hatalarını düzelttiği eğlenceli ve rekabet dolu bir eğitim ortamı oluşmasını sağlıyordu.

19 İhsanoğlu, a.g.e., s.251.

20 İhsanoğlu, a.g.e., s.251.

21 Açı, a.g.e., s.5.

22 Cahit Yalçın Bilim, Tanzimat Devrinde Türk Eğitiminde Çağdaşlaşma 1839-1876, Eskişehir: Anadolu Üniversitesi Yayınları, 1984, s.2; Akyüz, a.g.e., s.72, 75.

23 Özgönül Aksoy, Osmanlı Devri Sibyan Mektepleri Üzerine Bir İnceleme, İstanbul: İstanbul Teknik Üniversitesi Mimarlık Fakültesi, 1968, s.191; Açık, a.g.e., s.30.

24 Akyüz, a.g.e., s.74; Osman Ergin, Türkiye Maarif Tarihi (II. Basım), İstanbul: Eser Neşriyat, 1994, s.473.

25 M. Şakir Ülkütaşır, a.g.m., s.598. 


\subsection{Osmanlı Medreselerinde Arapça Öğretim Yöntemleri}

Medreselerde yaygin olarak kullanılan sarf kitapları el-Emsile, el-Binâ, el-Maksûd, el-ïzzî, el-Merâh ve eş-Şâfiye 'idi. Nahiv kitaplarından ise klasik dönemde yaygın olarak, iki el-Avâmil (Avâmil-i Cürcanîve Avâmil-i Birgivî), İzhâru'l-Esrâr, el-Kâfiye ve el-Kâfiye'nin Molla Câmî Şerhi kullanılmaktaydı. ${ }^{26}$

Osmanlı Medreselerinde kitap geçmek, yani bir seviyedeki temel ve yardımcı kitapları bitirdikten sonra, bir üst seviyeye ait kitapları okuma hakkını elde etme esasına dayalı yükselme sistemi vardı. Buna göre her seviyedeki medresenin öğretim süresinin, öğretmen ve talebenin gayretlerine ve öğrencinin kapasitesine bağlı olarak uzayıp kısaldığı söylenebilir. Osmanlı medreselerinde diğer derslerde olduğu gibi Arapça öğretiminde de birden fazla öğretim metodunun kullanıldığı göze çarpmaktadır. Bunlar; takrîr, ezber, kavrama, imlâ, tekrar, sorucevap, müzâkere ve münâzaradır. ${ }^{27}$ Öğrenme yönteminin esaslarını Ebû Amr b. Alâ şöyle özetlemiştir; ilmin birinci kuralı sükûnet, ikincisi iyi soru sormak, üçüncüsü iyi dinlemek, dördüncüsü iyi ezberlemek, beşincisi ise, elde edilen bilgiyi başkaları karşısında iyi savunmaktır. ${ }^{28}$ $\mathrm{Bu}$ yöntemlerin belli başlıları şunlardır:

Takrîr (Anlatma) Metodu; Medreselerde temel öğretim metodu olarak uygulan Takrîr yönteminde, eğitimin merkezinde müderris yer alır ve ders konusunu etraflıca ele alarak anlatır. Dersler, müderrisin seçtĭgi bir kitaptan okunan metinler ve açıklamalar üzerinden takrîr usûlüyle işlenirdi. "Açık kitap tedris usûlü" olarak da adlandırılan bu yöntemde müderris, metni sarf ve nahiv bakımından gerekli açıklamaları yaparak anlatırdı. ${ }^{29}$ Derslerin anlatımında kullanılan dil Türkçeydi. Türkçe, gerek Arap dili ile ilgili derslerin, gerekse diğer ilimlere ait Arapça yazılmış kitapların okutulduğu derslerin şerh ve izahları ile sözlü tartışmalarda kullanılmıştır. ${ }^{30}$ Öğrenciler halka şeklinde oturarak dersi dinlerler ve kendi nüshaları üzerinden müderrisin açıklamalarını takip ederek müderrisin mülahazalarını not alırlardı. Bazı hocalar aktif metot takip ederek dersleri talebeye okuttururlar, kendileri ancak gerekli hallerde müdahale ederek izahat yaparlard..$^{31}$

Ezber (Hıfz) Metodu; Kur'an-1 Kerim ve hadislerin nesiller boyu muhafaza edilmesini amaçlayan ezber yöntemi, medreselerdeki temel kaynakların öğrenilmesinde yaygın olarak kullanılmıştır. Özellikle dinî ve lisanî ilimlerin öğreniminde yöntem olarak önemli bir yere

26 Bkz. Nasuhi Ünal Karaaslan, “L'enseignement En Language Arabe Cehez Les Tures Ottomans Jusgu'aux”, Basılmamış Doktora Tezi, Paris: Tanzimat Üniversite De Paris-Sarbonne, 1976, s.111-134.

27 Yaşar, Sarıkaya, Medreseler ve Modernleşme, İstanbul: İz Yayıncılık, 1997, s.39.

28 George Makdisi, Ortaçağda Yüksek Öğretim -Íslâm Dünyası ve Hiristiyan Batı-,İstanbul: Gelenek Yayıncılık 2004, s.166.

29 Hasan Akgündüz, "Teşkilat ve İşleyiş Bakımından Osmanlı Medrese Sistemi”, Türk Dünyası Araştırmaları, 1992, sy. 80, s.84.

30 Akyüz, a.g.e., s.60; Sarıkaya, a.g.e., s.39.

31 Ramazan Şeşen, “Osmanlılar Döneminde Arap Dili ve Edebiyatı Öğretimi”, Studies On Turkish-Arap Relations, İstanbul: Türk Arap İlişkilerini İnceleme Vakfı Yayını, 1988, s.267; Akyüz, a.g.e., s.60. 
sahiptir. Medreselerde temel öğretim kaynağını oluşturan kitapların dili Arapçaydı. ${ }^{32}$ Ezber yoluyla öğrenmede büyük kolaylık sağlayan didaktik şiirler yazılmıştır. Bunun en çarpıcı örnekleri bin beyitten oluşan İbn Malik'in el-Elfiyye'si gibi gramer kitaplarıdır. Bu şiirler yoluyla, dilbilgisi kuralı ve en yaygın örneği öğrencinin zihnine yerleşiyordu. Herhangi bir amaç için hatırlanması kolayca mümkün oluyordu.

Yazdırma (İmla) Metodu; yazma ve okuma-kontrol şeklinde iki aşamada yapılırdı. İlk aşamada müderris, kendi hazırladığ 1 notları ve açıklamaları öğrenciye yazdırırdı. ${ }^{33}$ Müderris, bir cümleyi yazdırır sonra cümlede açıklanmaya ihtiyaç duyulan kısımların şerh, îzâh ve tefsirini yapar; öğrenciler de bu açıklamaları esas metnin sayfa kenarlarına not ederlerdi. ${ }^{34}$ Matbaanın Omanlı'ya geldiği dönemden itibaren kitapların baskıları yapılmaya başlanınca yazdırma (imla) yöntemi önemimi kaybetmiş, fakat müderrisin şerh ve düzeltmelerini öğrencinin metnin kenarlarına not alması üslubu devam etmiştir.

Soru-Cevap Metodu; Soru-cevap yönteminin medreselerde iki şekilde uygulandığ 1 görülmektedir. İlki, müderrisin öğrenciye soru sorup cevabını beklemesi, ikincisi ise, öğrencilerin belirli bir düzene göre müderrise soru sorabilmeleridir. ${ }^{35}$ Birincisinde; müderris soru sorarak dersi işler ve öğrencilerin anlayış kabiliyetlerini ölçer, onların cevap vermekte güçlük çektikleri konuları tespit ederek anlaşılmayan hususları tekrar anlatma imkanını elde ederdi. Böylece konuyu anlamayan veya takip edemeyen öğrenciler için dersi tekrarlamış olurdu. ${ }^{36}$ Ayrıca dersin sonunda da öğrencilerin konuyu tam olarak anlayıp anlamadıklarını test etmek için sorular sorardı. İkincisi usülde ise, öğrencilerin anlamadıkları konuları tespit ederek müderrise soru sormaları eksikliklerinin giderilmesinde daha faydalı, öğrenme kalitesini ve motivasyonunu artıran bir uygulamayd1. Medreselerde soru sormanın bir âdâbı vard1; öğrencinin hocası konuşurken sözünü kesmemesi, arkadaşı soru sorarken araya girmemesi, soru sormak için uygun ortam ve zamanı seçmesi ve başka bir amaç gütmeden yalnızca öğrenmek amacıyla soru sormas1 gerekirdi. ${ }^{37}$

Tartışma (Münâzara) Metodu; Tartışma metodu, Osmanlı Medreselerinde sıkça kullanılan metotlar arasındaydı. Daha çok medreselerin üst kademelerinde kullanılan bu yöntem, öğrencilerin konuyu kavrayarak çeşitli ortamlarda bilgi ve yaklaşımlarını savunabilecekleri yetkin bir seviyeye ulaşmalarını hedeflemekteydi. ${ }^{38}$ Müderrislerin okuttukları derslerle ilgili herhangi bir konuyu öğrenciler arasında tartışmaya açtıkları ve sonunda farklı fikirleri savunan taraflar arasında hakem olup kendi görüşlerini dile getirdikleri bilinmektedir. ${ }^{39}$ İmam

32 Hasan Akgündüz, Klasik Dönem Osmanlı Medrese Sistemi: Amaç-Yapı-İşleyiş, İstanbul: Ulusal Yayınları, 1997, s.413-414.

33 Makdisi, a.g.e., s. 169

34 Ahmed Çelebi, İslâm'da Eğitim Öğretim Tarihi, çev. Ali Yardım, İstanbul: Damla Yay., 1998, s.309.

35 Mustafa Şanal, “Osmanlı Devletinde Medreselerde Ders Programları, Öğretim Metodu, Ölçme ve Değerlendirme, Öğretimde İhtisaslaşma Bakımından Genel Bir Bakış”, Sosyal Bilimler Enstitüsü Dergisi, c. I (14), 2003, s.157.

36 Ahmed Çelebi, a.g.e., s.311.

37 Ahmed Çelebi, a.g.e., s.311.

38 Akgündüz, Klasik Dönem Osmanlı Medrese Sistemi, s.415.

39 Uzunçarşıl1, a.g.e., s.57. 
Burhânuddîn ez-Zernûcî bu konuda, “ Bir saat münâzara bir ay tekrardan hayırlıdır.” diyerek bu metodun üstünlüğünü belirtir. Yine o, "Tâlib-i ilim için münâzara, münâkaşa ve mutâraha (birbirine mesele sormak) zarurîdir. Zira münâzara ve müzâkere müşâveredir. Müşâvere ise doğruyu ortaya çıkarmak içindir." sözleriyle münâzara metodunun üstünlüğünü dile getirmiştir. ${ }^{40}$

Müzâkere Metodu; bilgilerin unutulmasını engellemek için öğrencilerin dersi karşılıklı olarak birbirlerine okumaları ve üzerinde kendi aralarında konuşmalarıdır. Taşköprülüzâde, Miftâhu's-Sa âde adlı eserinde, yaşıtlarıyla konuları karşılıklı gözden geçirmelerini ve birlikte incelemelerini öğrencilerin görevleri arasında saymaktadır. ${ }^{41}$ Medrese öğrencilerinin gündüz okudukları dersleri, yeniden gözden geçirmek, arkadaşlarından yeni bilgiler almak ya da karşılıklı fikir alış-verişinde bulunmak üzere akşamları başka medreselere gittikleri bilinmektedir. ${ }^{42}$ Böylelikle öğrenci hem eksik kalan bilgilerini düzeltme ve tamamlama, hem de bilgilerini pekiştirme firsatı bulmaktaydı.

Tekrar Metodu; öğrencinin konuları anlayıp kavramasını sağlamak için sıkça başvurulan bir yöntemdir. Osmanlı medreselerinde öğrenilen derslerin muîd $\mathrm{d}^{43}$ tarafından tekrar ettirilmesi öğretim sürecinin bir parçasıydı. Her medresede en az bir tane muîd bulunurdu. Muîdi olmayan medreselerde, en çalışkan öğrenci öğrenilenlerin tekrar ettirilmesi görevini üstlenirdi. ${ }^{44}$ Tekrar, metinlerin ezberlenmesine katkı sağlıyordu. Pek çok âlim, kendi öğrencilik yıllarında her bir dersi defalarca tekrar ettiklerini ifade ederler. Öyle ki, bir şeyin elli defa tekrar edilmedikçe tam olarak hafizaya yerleşmeyeceğini söyleyen âlimler bulunmaktaydı. ${ }^{45}$

\section{Tanzimat'tan Sonra Açılan Yeni Okullarda Arapça Dersleri}

Tanzimat Dönemi'nde her alanda başlatılan yenileşme (modernleşme) hamleleri sosyal ve kültürel alanlarda birçok olumlu gelişmelerin ortaya çıkmasına vesile olmuştur. Tanzimat Dönemi'nde eğitim alanında göze çarpan en önemli yenileşme hamlesi okullaşma faaliyetidir. Eğitim alanında teşkilatlanmaya önem verilerek her seviyede ve çeşitli mesleki alanlarda kurulan yeni okullar, memleketin her tarafına yaygınlaştırılmaya çalışılmıştır. Yeni Eğitim sistemin ilk ve orta öğretim basamağı 1840 yılından itibaren açılmaya başlayan Rüşdiye, İdadi, Sultani okullarıyla kurulmuş ve 1900 yılında Daru'l-fünun açılarak yüksek öğretim basamağı ihdas edilmiştir. Eğitim sisteminin esasını oluşturan bu okulların yanı sıra mesleki

40 İmam Burhânuddîn ez-Zernûcî, Tâ’limu"l-Müteallim. (İslâmda eğitim öğretim metodu), çev: Y.Veli Yavuz, 7. bs., İstanbul: Sahhaflar Kitap Saray1, 1995, s.105-107.

41 Ziya Kazıcı, Osmanlı’da Ĕgitim-Öğretim, İstanbul: Bilge Yayınları, 2004, s.167.

42 Ahmet Ulusoy, "Kuruluşundan 17. Yüzyıla Kadar Osmanlı Medreselerinde Eğitim-Öğretim Faaliyetleri”, Yayımlanmamış Yüksek Lisans Tezi, Konya: Selçuk Üniversitesi Sosyal Bilimler Enstitüsü, 2007, s.85.

43 Muîd: Sözlükte "tekrarlayan” anlamına gelen muîd kelimesi, medreselerde müderrisin verdiği dersi arkadaşlarına tekrar eden ve müderrise yardımcı olan öğretim elemanıdır. Muîdler, sadece müderrisin okuttuğu derslerin tekrarı ve müzakeresiyle değil aynı zamanda talebenin gözetimiyle de ilgileniyordu. Bkz. Sâmî Es-Sakkâr, "Muîd", TDV İslâm Ansiklopedisi, https://islamansiklopedisi.org.tr/muid--medrese (13.06.2020).

44 Mefail Hızlı, Mahkeme Sicillerine Göre Osmanlı Klasik Dönemi Bursa Medreselerinde Eğitim-Öğretim, Bursa 1997, s.157.

45 Makdisi, a.g.e., s.167. 
alanlarda devlet tarafından birçok okul açılmıştır. Ayrıca özel teşebbüs girişimlerine müsaade edilmesiyle rüşdiye, idadi ve sultani seviyelerinde özel okullar açılmıştır.

Bu yeni okullardaki öğretimin eski öğretim sistemine göre en önemli fark1; okul müfredatında yer alan derslerin belirlenen saat sayısına bağlı kalınarak, haftalık plan/programlarının yapılması ve derslerde Usül-i Cedid ${ }^{46}$ adıyla yeni öğretim anlayışı ve yönteminin uygulanmasıdır. Yani Medreselerde uygulanan kitap geçme sistemi terk edilerek, günümüzde de geçerli eğitim programları uygulamaya başlanmıştır. Ayrıca yeni okullarda dini ilimlerin öğretimi ağırlı̆̆ ve önceliği terk edilerek, fen ve sosyal alanlarına ait derslerin sayısı artırılmıştır. Bu dönemde açılan belli başlı okullar ve programlarındaki Arapça dersleri ile öğretim yöntemleri hakkında kısa bir değerlendirme yapalım.

\subsection{Rüşdiyeler ve Arapça Öğretimi}

Rüşdiye, rüşd çağına ulaşmış çocuklara mahsus okul anlamındadır. Hem askeri okullara öğrenci hazırlamak hem de iyi memur yetiştirmek amacıyla, II. Mahmut devrinin sonlarında Meclis-i Umûr-1 Nafia ${ }^{47}$ tarafından açılmasına karar verildi. ${ }^{48}$ İlk rüşdiye mektepleri olarak kabul edilen Mekteb-i Maârif-i Adli 1254/1838 ve Mekteb-i Ulûm-1 Edebiye 1255/1839'da

46 Usûl-i Cedit'in Eğitim Anlayışı; çağın gereklerine uygun eğitim öğretim yapmak ve öğrencileri okuma yazma başta olmak üzere devrin gerektirdiği temel teknik ve bilgiyle donatmak olmuştur.

Usûl-i Cedid eğitim anlayışııı İsmail Gaspıralı "Rehberi Muallim Ya Ki Muallimlere Yoldaş” adlı risalesinde hareketle şu şekilde ifade etmiştir:

- Dini bilgiler öncelikli olmakla birlikte öğrenciye sağlam bir okuma yazma eğitimi vermek ve günlük ihtiyacı olan bilgileri sunmak amaçlanır.

- Bir öğretmene otuz, kırktan fazla öğrenci verilmemelidir.

- Sadece erkek çocukları değil, kız çocukları da okutulmalıdır.

- Öğretimde bireysel ilerleme değil grup olarak sınıf halinde ilerleme ve başarı önemlidir.

- Bir günde, en fazla, sabahtan üç saat, öğleden sonra iki saat olmak üzere toplam beş saat ders yapılmalıdır. Teneffüsler on dakika, öğle arası kırk beş dakika olacaktır.

- Cuma günü ve milli bayramlarda okul tatil olmalı; yazın ya okul kapanmalı ya da dersler hafifletilmelidir.

- Bir günde bir dersten en fazla bir saat ya da kırk beş dakika görülmelidir. Aksi, öğrencide bıkkınlık ve yılgınlığa yol açar.

- Öğrenciyi dövmemek ve azarlamamak gerekir. Dersi öğretmek için ceza değil teşvik gerekir.

- Her haftanın sonunda öğrencinin o haftaki başarı durumunu gösteren bir belge verilmelidir.

- Sinıflar büyük, ferah, aydınlık ve temiz olmalıdır.

- Kara tahta, sıra gibi modern eğitim araçlarından yararlanılmalıdır.

- Namaz sureleri dışında ezbere yer verilmemeli, öğrencinin konuyu anlaması ve nakledebilmesi üzerinde durulmalıdır.

- Yazma ve okuma dersleri toplu olarak yapılmalıdır.

- Temel eğitim için beş sene çoktur, iki sene yeterlidir. Diğer üç senede çeşitli zanaatlar öğretilmelidir.

- Bir konu tam öğrenilmeden diğerine geçilmemelidir.

- Eğitim bütün sınıflar ve öğrenciler için aynı anda başlayıp aynı anda biter.

- Her dersin sinavı olmalıdır.

- Okuma yazma öğretildikten sonra, önce Türkçenin kuralları, sonra Rusça ve Arapçanın kuralları öğretilmelidir.

Bkz.: Gaspıralı İsmail, Eğitim Yazıları, Haz.: Yavuz Akpınar, İstanbul: Ötüken Neşriyat, 2017, s. 471-505.

47 Meclis-i Umur-1 Nafia eğitim işleriyle ilgilenmek üzere bir meclis olarak 7 Temmuz 1838'de kuruldu. Modem eğitim alanında teşkilatlanma çalışmaları bu meclisin kuruluşu ile başlamıştır.

48 H. Ali Koçer, Türkiye Modern Eğitiminin Doğuşu ve Gelişimi, İstanbul 1991, s.40; Akyüz, a.g.e., s.129. 
açılmıştır. Öğretim süresi iki yıl olan bu okullara Sıbyan Mektebini bitirenler alınmış, çocuklar sıralara oturarak ve sınıf sınıf ders yapılmıştır. ${ }^{49}$ 1261/1845'te Muvakkat Meclis-i Maârifi tarafından Rüşdiyeler orta dereceli okul olarak kabul edilerek, Osmanlı eğitim sistemi içindeki yeri belirlenmiştir. ${ }^{50}$

1286/1869 nizamnamesiyle öğretim süresi dört yıl olarak belirlenen rüşdiyelerde birinci yılda Sarf-i Arabî, ikinci yılda Nahiv, dördüncü yılda Risale-i Erba'a adlı dersler okutulmuştur. Üçüncü yılda Arapça ders yoktur. ${ }^{51}$ Arapça derslerin programda haftalık dağılımı ikişer saattir. 1294/1877 y1lına ait ders programında yer alan Arapça dersleri şunlardır: ${ }^{52}$

"1.Sınıf: Medhâl-i Kavaid

3.Sinıf: Arabî (Arapça metinler) sanatlar)"
2.Sınıf: Arabî

4.Sınıf: İlm-i Belagat (Arapçada yer alan edebi

\section{Rüşdiyelerde Arapça Öğretimi}

Yöntem arayışlarının ilki, 1264/1847 yılında Mekâtib-i Umumiye Müdürü Kemal Efendi tarafından gerçekleştirildi. Kemal Efendi Davutpaşa'da bir rüşdiye açtı ve bu okula bir yıl hazırlık sınıfı, olmak üzere dört yıllık bir program hazırladı. ${ }^{53}$ Burada Usûl-i Cedid üzere Arapça öğretimi yapıld1 ${ }^{54} \mathrm{O}$ dönemde usûl-1 Cedid ile Arapça öğretimi hakkında kaynaklarda şöyle bahsedilmektedir: ${ }^{55}$

"Bu Usûl-1 Cedid ile rüşdiye talebesi idraklarının kabul edebileceği mertebe açık ve kolay tabir ile Arabî ve Farisiye başlatılmıştır. Öğretimin sonunda talebe Arapçadan sarf cümlesini ve Avamil'i tamamlamıştır. el-Haletuhazi okudukları Arabî derslerini tercüme etmeye başlamışlardır."

Rüşdiyelerde Arapça öğretiminde başlangıçta klasik kaynaklar okutulmasına rağmen yukarıdaki açıklamalardan da anlaşılacağı gibi öğretimde yeni bir yöntemin benimsendiğini görülmektedir. “...açık ve kolay tabir ile Arabî ...” ibaresinden Arap dili gramerinin öğrencilere ana dilleri ile açık bir şekilde anlatılması, bu anlatımda "...idraklarının kabul edeceği mertebe..." kıstasıyla küçük yaştaki talebelerin seviye ve kabiliyetlerine uygun bir ifade tarzının geliştirilmesi söz konusudur. "Arabî derslerini tercüme etmeye başlamışlardır” ifadesi ile öğrendiği dersleri ve seviyesindeki metinleri anlayıp, tercüme edebilme yeteneği kazandırıldığı söylenebilir. Bu konuda Ahmed Naim Bey'in değerlendirmesi şöyledir: ${ }^{56}$

49 Akyüz, a.g.e., s.129.

50 İhsanoğlu, a.g.e., s.307; Kodaman, a.g.e., s.92.

51 Kodaman, a.g.e., s.111.

52 Mahmud Cevad İbn el-Şeyh Nafi, Maarif-i Umumiye Nezareti Teşkilatı ve Ícraatı, İstanbul: Matbaa-1 Amire, 1338, s.131.

53 İlhan Tekeli ve Selim İlkin, a.g.e., s.64.

54 Ergin, a.g.e., s.444-445; Bilim, a.g.e., s.48-49; Akyüz, a.g.e., s.180.

55 Ergin, a.g.e., s.445.

56 A. Turan Arslan, Son Devir Osmanll Alimlerinden Mehmed Zihni Efendi, İstanbul: Marmara Üniversitesi İlahiyat Fakültesi Vakfı, 1999, s.93. 
“Arapça tedrisatında atılan ilk ileri adım, Rüşdiye mekteplerinin açılması üzerine, Arapça kaideleri çocuklara Türkçe ve özlü bir şekilde belletmek ve ibaresi Arapça olan kitaplar yerine Türkçe mefhumlar ezberletmek usûlü olmuştur."

1265/1848'de Rüşdiyelerden yirmi kadar çocuk, Meclis-i Maârif önünde imtihan olmuşlardır. Bu çocuklar henüz 8 yaşındadır. Arapçadan Emsile, Bina, Farsçadan iki adet ufak risaleden başka bir şey okumadıkları halde soruları güzelce cevaplamışlar, bu dillerde üç yılda büyük bir çaba ve çalışma ile yüksek derecede bilgi kazandıklarını göstermişlerdir. ${ }^{57} \mathrm{Bu}$ durum padişah Abdülmecid Han'a bildirilmiş, padişah da çocukların bir de kendi huzurunda imtihan edilmesini istemiştir. Çocuklar padişahın ve vekillerin önünde, bir kez daha imtihan edilmiştir. Kemal Efendi tarafından çocuklara önce Arapça fiil çekimleri, sonra Farsçadan bazı cümleler okutturulup anlamları sorulmuş ve öğrencilerin konuşmaya epeyce yetenek kazandıkları görülmüştür. ${ }^{58}$ Yapılan Arapça sınavda çocuklar öncelikle sarftan imtihan edilmişlerdir. Başarılı olan öğrencilere, fiil veya isim çekimleri gibi ezbere dayalı teorik bilgiler sorulmuştur. İkinci imtihanda "cümleler okutturulup anlamlarının sorulması", cevap üretmeye dayalı bir beceri sınavıdır. Bu da, usûl-i cedide ile öğretimde öğrencinin dinleme-anlama ile konuşma becerisinin geliştirilmesine yönelik çalışmalar yapıldığını göstermektedir. Arapça öğretiminde Usûl-1 Cedid girişimiyle başlayan yeni yöntem arayışı çeşitli şekil ve yaklaşımlarla Tanzimat dönemi boyunca devam etmiştir. Arapçayı kolay ve etkili bir yolla öğretme amaçlı birçok kaynaklar üretilmiş ve Arapça öğretiminde kullanılmıştır.

\section{2. İdadîler ve Arapça Öğretimi}

İdadî adıyla anılan okullar ilk olarak 1261/1845'te, Askeri okullara girmek isteyenlerin bilgi bakımından eksikliklerini tamamlamak üzere ordu merkezlerinde açılmıştır. ${ }^{59}$ İdadî teriminin bir orta öğretim kurumunun adı olarak kabul edilmesi, 1286/1869 da Maârif-i Umumiye Nizamnamesi'yle olmuştur. Bu nizamnameyle her bin haneli kasabada bir İdadî açılacaktı ${ }^{60}$ İdadîler dört yıllık rüşdiyelerin üzerine üç yıllık bir okul olarak düşünülmüştü. ${ }^{61}$ Okutulacak dersler şunlardı: Türkçe kitabet ve inşa, Fransızca, Kâvânin-i Osmaniye, İlm-i Servet-i Milel, Coğrafya, Tarih-i Umûmi, Cebir, Hesap, Hendese, Hikmet-i Tabiiye, Kimya, Resim..$^{62}$ Bu programda Arapça ve Farsça dersleri yoktur. ${ }^{63}$ 1286/1869 Nizamnamesiyle oluşturulan programda Arapça derslere yer verilmemesine rağmen 1290/1873'de açılan ilk idadi mektebinin programında Arapça dersi mevcuttur. ${ }^{64}$

57 Akyüz, a.g.e., s.180.

58 Akyüz, a.g.e., s.180-181.

59 Akyüz, a.g.e., s.144; İlhan Tekeli ve Selim İlkin, a.g.e., s.68.

60 Akyüz, a.g.e., s.145; H. Ali Koçer, a.g.e., s.130; Kodaman, a.g.e., s.114-115.

61 Akyüz, a.g.e., s.145; H. Ali Koçer, a.g.e., s.130; İlhan Tekeli ve Selim İlkin, a.g.e., s.68.

62 Kodaman, a.g.e., s.115; İhsanoğlu, a.g.e., s.319.

63 Akyüz, a.g.e., s.145; Hüseyin Atay, Osmanlılarda Yüksek Din Eğitimi, İstanbul: Dergâh Yayınları, 1983, s.188.

64 Kodaman, a.g.e., s.115. 
1309/1892 yılında idadî programlarında esaslı bir ıslahat yapılmış ve idadîlerin öğretim süresi vilayet merkezlerinde yedi, sancaklarda ise beş yıl olarak belirlenmiş ve II. Meşrutiyet dönemine kadar uygulanmıştır. ${ }^{65}$ Yapılan yeni düzenlemeye göre, sancak merkezlerinde bulunan beş yıllık idadî mekteplerinin ders programında Arapça ders dağılımı şöyledir: ${ }^{6}$

\begin{tabular}{llllll} 
Sinıflar & 1 & 2 & 3 & 4 & 5 \\
\hline Arabî & 3 & 3 & 3 & 3 & 2
\end{tabular}

Vilayet merkezlerinde kurulan İdadi mekteplerinin 6 ve 7. Sınıflarına Arapça ders konulmamıştır. İlk beş yıllık program aynıdır.

\section{İdadîlerde Arapça Öğretimi}

İdadîlerde Arapça ve Farsça dersleri Türkçeye yardımcı mahiyette işleniyordu ve gramer ağırlıklıydı. Arapça ve Farsçadan Türkçeye geçmiş kelimelerin okunup anlaşılması amaçlanıyordu. ${ }^{67} \mathrm{Bu}$ dönemde, Türkçe öğretiminin önem kazanmasına binaen, öncelikli olarak Türkçeye geçen Arapça kelime ve yapıların öğretimi söz konusu olmuştu. O halde Arapça dersleri daha çok sarf öğretimi ağırlıklı olarak kelime bilgisi amacına yönelik işleniyordu.

“... ancak Türkçe, Arabî ve Farisi' den lafiz istiare ederek zînetlenmekle beraber hattizatında müstakil bir lisan olup kendine mahsûs sarf ve nahiv kavâ'idi bulunmak tabii olduğundan, Türkçenin kavâ’idi tedris olunduğu sırada Arabî ve Farisi kavâ'idi dahi mufassalan mecz olarak gösterildiği halde çocukların zihni pek ziyade karışıklığa düşerek, talebenin ana dillerinin tahsiline muvaffak olamadıkları... bununla beraber Türkçe, Arabî ve Farisiye ihtiyaçtan tamamı ile vareste olamayacağından, mezkûr iki lisandan alınıp Türkçeye geçen ve Türkçe gibi tasarruf olunan lafız ve kelimelerin Türkçede kullanılış tarzlarıyla yalnız bunlara tatbîki câiz olmak üzere musta 'mel bulunan Arapça ve Farsça kavâ'idi dahi, muhtasar surette gösterilmek münasip addolunarak bu dersin programı bu yolda tahsîs edildi." 68

1314/1898 yılı programında Arapça hakkındaki görüş değişmiş ve Arapçanın öğretiminin zaruri olduğu kanaati ortaya çıkmıştır:

"Lisan-1 Arap, Lisan-1 din olduğundan buna intisap herkes için lazım olduğu gibi Arapça tedvin olunmuş birçok kütüb-i mu’teber-i ilmiyyeden istifade edebilmek üzere tedris olunacaktı. Farisi içinde vaziyet aynı idi." ${ }^{69}$

Bu programda Arapçanın ayrı bir dil olarak öğretimine ağırlık verilmiştir. “...Kütübi mu’teberi ilmiyyeden istifade..." ifadesinden yüksek derecede bir okuma-anlama seviyesine ulaşmanın

65 F. Reşit Unat, Türkiye'de Eğitim Sisteminin Gelişimine Tarihi Bir Bakış, Ankara: Milli Eğitim Bakanlığı, 1964, s.45; H. Ali Yücel, Türkiye 'de Orta Öğretim, Ankara: Kültür Bakanlığ1, 1994, s.93-94; Kodaman, a.g.e., s.126128 .

66 Yurdagül Mehmedoğlu, Tanzimat Sonrasında Okullarda Din Eğitimi (1838-1920), İstanbul: Marmara Üniversitesi İlahiyat Fakültesi Vakfi Yayınları, 2001, s.140.

67 Halil Aytekin, İttihat ve Terakki Dönemi Eğitim Yönetimi, Ankara: Gazi Üniversitesi Eğitim Fakültesi Yayınları, 1991, s.106.

68 Yücel, a.g.e., s.175.

69 Yücel, a.g.e., s.175-176. 
hedeflendiği anlaşılmaktadır. Kullanılan yöntem konusunda ise, söz konusu kitaplardan istifade edebilecek kadar okuma-anlama seviyesinin hedeflenmesi, yazma ve konuşma becerilerin bir kenara bırakıldığını düşündürmektedir. Belirlenen bu hedefler doğrultusunda dilbilgisi-tercüme yönteminin uygulandığını söyleyebiliriz.

1329/1911 y1lı yedi senelik idadîlere mahsus ders cetvelinde bulunan Arapça dersleri: ${ }^{70}$

$\begin{array}{llllllll}\text { Siniflar } & 1 & 2 & 3 & 4 & 5 & 6 & 7 \\ \text { Arabî } & 3 & 2 & 1 & 2 & 2 & 2 & 3 \\ \text { Elsine } & - & - & - & 2 & 2 & 1 & 1\end{array}$

Yedi yıl öğretim süreli bu idadîlerin altı ve yedinci sınıflarında, "Arabî” dersinin "tatbikat-1 arabîyye" ibaresiyle uygulama dersleri olarak icra edildiği anlaşılmaktadır. Bu derslerde yeni metodla Arapça öğretimi yapılmıştır. Medrese ve Rüşdiyelerde öğrencilerin Arapça kaideleri ezberledikleri halde, Arapça konuşamadıkları ve yazamadıklarının şikâyet konusu olması üzerine, Maârif Nezareti bu şikayetleri göz önünde tutarak idadîlerin programlarını yeniden düzenledi. İstanbul idadîlerinin beş, altı ve yedinci sınıflarında öğrencilerin Arapça dil kabiliyetlerinin geliştirilmesi hedeflendi. Öğrencilere bu aşamada Türkçe tercümeyle birlikte, sarf ve nahiv kaidelerinin uygulamaları yaptırıldı. Ayrıca konuşma becerisini kazanmaları için de Türkçeden Arapçaya veya Arapçadan Türkçeye sözlü tercüme çalışmaları planlandı. Bunlar idadî programlarında görülen yeni bir uygulamaydı. ${ }^{71}$

\subsection{Sultanîler ve Arapça Öğretimi}

Sultanîlerin açılış gayesi kaynaklarda şöyle ifade edilmektedir: Her türlü lisan ve ilmi bilen insanlar yetiştirmek, her sınıf insanın kendini yetiştirmesine imkan sağlamak, Osmanlı Devleti'nde yaşayan unsurların kaynaşmasına vesile olması amacıyla ve usul-i cedide eğitim anlayışına uygun olarak açılacak okullara numune teşkil etmek üzere Mekteb-i Sultani kurulmuştur. ${ }^{72}$ “...usul-i cedide eğitim” ifadesi bu okullarda da yeni eğitim anlayışının uygulanacağı güçlü şekilde vurgulanmıştır. Bu okulların ilki olan Galatasaray Sultanisi, 1 Eylül 1868 (20 Ağustos 1284) tarihinde Galatasaray’daki binasında 348 öğrenciyle öğretime başladı. ${ }^{73}$ Öğretim dili Fransızca olarak kabul edilen Sultanî'de okutulan dersler şunlardır: ${ }^{74}$

"Fransızca, Türkçe, Grekçe, Ahlak, Latince, Umumi Tarih ve Osmanlı Tarihi, Coğrafya, Matematik, Kozmografya, Mekanik, Fizik, Kimya, Ekonomi, Tabiat Tarihi, Hukuk, Umumi Edebiyat"

70 Yücel, a.g.e., s.149.

71 Yusuf Ziya Bildirici, “Tanzimat’tan Cumhuriyet'e Türkiye’de Arapça Öğretimi”, Basılmamış Yüksek Lisans Tezi, Ankara: İnkılap Tarihi Enstitüsü, 1987, s.41-42.

72 Mektebi Sultaninin Ellinci Sene-i Devriyesi Münasebetiyle, İstanbul: Mabaa-1 Amire 1919, s.4.

73 Yücel, a.g.e., s.9; F. Reşit Unat, a.g.e., s.47; Ergin, a.g.e., s.484; Adnan Şişman, Galatasaray Mekteb-i Sulatnisi'nin Kuruluşu ve Illk Öğretim Yıllarl (1868-1871), İstanbul: Edebiyat Fakültesi Matbaası, 1989, s.23.

74 Şișman, a.g.e., s.18-19. 
Yapılan bu ilk programda Arapça dersi yoktur. Fakat daha sonra programda pek çok değişiklikler yapılmıştır. Nitekim 1286/1869 Nizamnâmesiyle Sultanî dersleri arasına Arapça, Farsça gibi dersler konulmuştur. ${ }^{75}$ 1294/1877 yılında Maarif Nazırı Münif Paşa tarafından okulun müdürlüğüne, Ali Suavi atandı. Ali Suavi, okulun idari teşkilatı, öğrenci ve öğretmen disipliniyle alakalı bir dizi ıslahat gerçekleştirdi. Ders içerikleri bakımından yapılan en önemli yenilik, ders programlarının değiştirilerek Arapça, Farsça, Akaid, Arap Edebiyatı ile Türkçe'nin öncelikli ve zorunlu dersler haline getirilmesidir. ${ }^{76}$

Galatasaray Sultanîsi kendi özel programı ve öğretim sistemini, yeni açılan Sultanîlerden istisna olarak II. Meşrutiyet devrinde de aynen korumuştur. ${ }^{77}$

\section{Galatasaray Sultanîsi’nde Arapça Dersleri ve Öğretim Usûlü}

1316/1898-1317/1999 yılı okul programında Arapça dersleri şöyledir: ${ }^{78}$

"Sunuf-1 İptidaiye (Üç sınıf): Arapça ders yoktur.

$\underline{\text { Sunuf-1 Tâliye }}$

1.Sinıf: Arabî

2.Sınıf: Arabî

3.Sinıf: Arabî $\underline{\text { Sunuf-1 Âliye }}$

4.Sinıf: Arabî

5.Sinif: Arabî ve Belagât

6.Sınıf: Arabî ve Belagât"

Arapçanın geniş şekilde öğretimi Tâlî ve Âlî sınıflarında idi. Tâlî sınıflarında Arapça öğretimi uygulamalı, Âlî sınıflarında nahiv öğretimi ve tercüme çalışmalarıyla devam etmekteydi. Arapça kaidelerin öğretimi için hazırlanan kitaplarda uygulama ve üretime dayalı bir yöntem benimsendiği göze çarpmaktadır. Bu yöndeki uygulamalar üst sınıflarda daha da yoğunlaştırılarak Türkçeden Arapçaya veya Arapçadan Türkçeye çeşitli alıştırmalarla öğrencilerin dil becerilerini kazanmaları hedeflenmiştir. İdadî programlarından farklı olarak Arap Edebiyatı Tarihi ile ilgili bilgiler verilmiş, meşhur edip ve şairlerin eserlerinden beyit ve kıtalar ezberlettirilmiştir. ${ }^{79}$ Galatasaray Sultanîsi'ne ait mevcut programlar Usûl-1 Cedide ile Arapça öğretimi yapıldığını göstermektedir. İptidai sınıflarında Arapça dersi bulunmamasına rağmen, Osmanlı Türkçesi öğretimi içerisinde Arapça kaidelerin öğretildiği anlaşılmaktadır. Bu tarz öğretim Sultanî’nin Tâlî ve Âlî kısımlarındaki Osmanlıca öğretimi sirasinda da yapılmaktayd1. ${ }^{80}$

Mekteb-i Sultanî’ de idadilerde olduğu gibi dil öğretimini kolaylaştıracak metotların arayışı sürüyordu. Mesela; Müptedi sınıfında okutulan Mekteb-i Sultanî öğretmenlerinden Cemil Bey'in Sarf-ı Arabî kitabı öğrenciye Arapça sarfını kolay şekilde öğretmeyi hedeflemiştir. Yine Mehmed Zihni Efendinin, önsözünde; Arapça gramerini kolay öğretmek amacıyla hazırladığını

75 Kodaman, a.g.e., s.135-136.

76 Mehmedoğlu, a.g.e., s.147.

77 Koçer, a.g.e., s.132.

78 Mehmedoğlu, a.g.e., s.148.

79 Bildirici, a.g.e., s.50-51.

80 Bildirici, a.g.e., s.50. 
ifade ettiği el-Muntehab ve el-Muktedab isimli eserlerini, bu dönemde yöntem arayışlarının önemli numuneleri olarak değerlendirmek yerinde olur.

İsmail Ertaylan, Galatasaray Sultanî'si'ndeki hatıratında Arapça öğretmeni Zihni Efendi hakkındaki düşüncelerini ifade ederken Arapça öğretimi ile ilgili şunları belirtmektedir: ${ }^{81}$

“...Arapçayı güya evvelki sınıflarda öğrenmiş olduğumuz için kendisi bize Arap Edebiyatından parçalar yazdırır, okutur, izah eder, kelimenin çeşitli anlamları üzerinde durur, güzel sözlerle alakamızı canlandırmaya çalışırdı. Büyük şairlerin hal tercümelerinden kısa bilgiler verir, bikmadan usanmadan anlatırdı..."

Ahmed Naim Bey bu okuldaki Arapça öğretimini şöyle değerlendirmektedir: ${ }^{82}$

“...ilimlerin ve fenlerin tedris edildiği bir mektepte Arapça ile haftada iki saat meşgul olunca, yine o kadar bir müddet içinde nahiv ve sarf kaidelerini gayet mazbut olarak bellemek, ibareyi sökmeye bir meleke ve kudret peyda etmek, mektepten çıktıktan sonra az zaman içinde bu tahsili layık olduğu dereceye ulaştırmak imkanının mevcut olduğunu gösterdi... Lisan kaidelerini tatbikatı ile beraber öğretmekten ibaret olan bu usûllerin ..."

Maarif Nezareti Batı'da kullanılan dil öğretim yöntemlerini de takip ediyordu. Almanyalı muallim Berliç'in kullandığı usûlün (Berliç Usûlü ${ }^{83}$ ) Batı'da çok faydalı olduğu görülerek bu yöntemin Arapça öğretiminde uygulanmasına karar verildi. Bu karar üzerine özel bir heyet tarafından gerekli düzenlemeler yapıldı ve oluşturulan üç kişilik bir komisyon tarafından Sultanilerde okutulmak üzere Berliç usulüne uygun olarak Ta 'limu'l-Lugati'l-Arabîye a 'lâ Tarîkat-ı Berlitz isimli eser kaleme alındı. ${ }^{84}$

\subsection{Dâru'l-Muallimîn}

16 Mart 1848 (1265)'de İstanbul Çarşamba'da, açılmasına hız verilen Rüşdiyelere öğretmen yetiştirmek üzere Kemal Efendi tarafından Dâru'l-Muallimîn mektebi açıldı. ${ }^{85}$ İlk müdürü okulun nizamnâmesini hazırlayan Ahmed Cevdet Paşa'dır. ${ }^{86}$ Tahsil süresi üç yıldır. ${ }^{87}$ Okulun açılış gerekçesi özetle şöyledir: ${ }^{88}$

81 Arslan, Mehmed Zihni Efendi, s.166.

82 Babanzade Ahmed Naim'in Hacı Mehmed Zihni Efendi'nin el-Muntahab ve el-Muktadab adlı eserinin önsözünde yer alan Arapça öğretimi ile alakalı sözlerinden. Bkz. Hacı Mehmed Zihni Efendi, el-Muntehab ve'l-Muktedap fi Kavadi 's-Sarf ve 'n-Nahv, İstanbul: Şireket-i Mürettibye Matbaası, 1303.

83 Berliç usûlü; öğrencinin yakın çevresinde devamlı gördüğü eşya, şahıs ve tabiattaki manzaralarla bunlara delalet eden isimler, sıfatlar, fiiller ve edatlardan cümle ve hikayeler üreterek dilin doğru, akıcı ve düzgün söylenmesine ve irab kaidelerine uygun olarak öğrenmekten ibaretti.

84 Bu kitap Arapça öğretim kaynaklarının yöntemlerinin incelenmesi bölümünde ele alınacaktır. Bkz. Bu makale, bölüm 4.1. Ta'limu'l-Lugati'l-Arabîye a'lâ Tarîkat-1 Berlitz.

85 Türkiye Diyanet Vakfı İslam Ansiklopedisi, Cemil Öztürk, "Darulmuallimin" maddesi, c. VIII, İstanbul: Türkiye Diyanet Vakfı Yayınları, 1993, s.551-552; Akyüz, a.g.e., s.154; Ergin, a.g.e., s.571'de (Okulun açıllıs tarihini 1847 olarak vermektedir); Koçer, a.g.e., s.56.

86 İhsanoğlu, a.g.e., s.310; Abdülkadir Özcan, “Tanzimat Döneminde Öğretmen Yetiştirme Meselesi”, 150. Yıldönümü Uluslararası Sempozyum Bildiriler, Ankara: Milli Kütüphane 1991, s.444.

87 İhsanoğlu, a.g.e., s.311; Koçer, a.g.e., s.56; Özcan, a.g.m, s.445.

88 Bayram Kodaman ve Abdullah Saydam, “Tanzimat Devri Eğitim Sistemi”, 150. Yıldönümü Uluslararası Sempozyum Bildiriler, Ankara: Milli Kütüphane 1991, s.492. 
“...açılan mekteplerde çocuklara öğretilmesi lüzumlu ilim ve fenlerin kolayca verilebilmesi için hocaya ihtiyaç vardır. Bu ihtiyacı karşılamak üzere Padişahın (Sultan Abdülmecid) emriyle Fatih semtinde Dâru'l-muallimîn inşa edilmiştir..." 89

Bu okulun açılması Tanzimat dönemi yöneticilerinin, modern eğitim ve öğretimin, yeni usûllere göre yetişmiş öğretmenler vasıtasıyla gerçekleştirilebileceği gerçeğini gördüklerini ve bu ihtiyacı karşılamak üzere bu okulu açtıklarını göstermektedir. Öğretmen yetiştirme meselesinin ön plana çıkması, Maarif-i Umumiye Nizamnâmesi'nde öğretmen okullarına gereken önemin ve yerin verilmesinde etkili olmuştur. Nizamnâmede rüşdiye, idadi ve sultanilere öğretmen yetiştirmek için Dâru'l- Muallimîn-i Kebir adı verilen bir öğretmen okulunun tesisi öngörülmüştür. ${ }^{90}$ Nizamname uyarınca Rüşdiye ve Sıbyan Okulları şubesi oluşturulmuştur. ${ }^{91}$

1291/1874 yılında İstanbul Dâru'l-muallimîni adı altında sıbyan, rüşdiye ve idadi şubelerini içeren bir okul haline getirilmiştir. Sıbyan şubesinde öğretim süresi iki yıl, rüşdiye ve idadi şubelerinde üç yıl idi. ${ }^{92}$.

\section{Dâru'l-Muallimîn'de Arapça Dersleri ve Öğretim Usûlü}

1265/1848 senesinde açılan ilk Dâru'l-muallimîn'in ders programında her üç sınıfta da Arapça dersi bulunmaktaydı. Programında; Elifba, Sarf, Nahiv, Meani başta olmak üzere çeşitli dersler yer almaktayd1. ${ }^{93}$

1286/1869 nizamnâmesine göre kurulması düşünülen Dâru'l-Muallimîn-i Kebir'in ders cetvellerinde Arapça dersleri şöyledir:

"Rüşdiye şubesi: Üç y1l süreli olan Edebiyat sınıfında tertib-i cedîd üzere tedrise iktisab kesbedebilecek derecede Arabî ve Farisî (Ulûm şubesinde Arapça yoktur.)

İddadi şubesi: Edebiyat Şubesi; Tahsil süresi üç yıl, edebiyat sınıfında Arabî ve Farisî’den tercüme, (Ulûm şubesinde Arapça yoktur.)

Sultanî Şubesi: Üç yıllık Edebiyat şubesinde mükemmel Arabî ve Farisî. (Ulûm şubesinde Arapça yoktur.)" 94

Darul-mualliminde uygulanan Arapça öğretiminde uygulanan iki yenilik dikkat çekicidir. Birincisi; yayınlanan bir talimname ile Anadili Arapça olan öğretmenlerin konuşma derslerinin öğretimi için görevlendirilmesidir; 4 Temmuz 1884 (1302) tarihli Şuray-1 Devlet tarafindan yazılan mazbatada, Arapça konuşulan yerlerdeki mekâtib-i rüşdiye muallimlerinin konuşma eksiği çektiği tespit edilmiş ve bu konuşma eksikliğini gidermek için şu tedbir düşünülmüştür: ${ }^{95}$

89 Özcan, a.g.m., s.444.

90 İhsanoğlu, a.g.e., s.311; Cavit Binbaşığlu, Türkiye'de Eğitim Bilimleri Tarihi Üzerinde Bir Araştırma: Öğretmen Yetiştirme Açısından, Ankara: Milli Eğitim Bakanlığı Yayınları, 1981, s.41.

91 İhsanoğlu, a.g.e., s.311; Binbaşığlu, a.g.e., s.41.

92 Öztürk, "Darulmuallimin", s.552.

93 Bilim, a.g.e., s.67-68; Koçer, a.g.e., s.56-57.

94 Özcan, a.g.m., s.456.

95 Ergin, a.g.e., s.573. 
“...Suriye ahalisinden oldukça Türkçe öğrenmiş ve lisanın sarf ve nahvini görmüş kişilerden on kişi celbiyle Dâru'l-muallimîn'de tavzif edilmesi hakkında mazbata tanzim ve takdim kılınmış..."

İkincisi ise; Arapların yaşadığı bölgelerde görev alacak öğretmen adaylarının mezuniyetten önce Halep, Bağdat gibi Arapça konuşulan bölgelere belli dönemlerde gönderilerek Arapçayı pratik yapmaları projesidir; ${ }^{96}$

“Dâru'l-muallimîn'de bulunan talebe Cevami-i Şerif'e usûlü üzere Lisan-i Arabî’nin kavâid-i sarfiyye ve nahviyyesini tahsil etmiş, mantık ve meaniyi okumuş kimseler ise de öteden beri burada kaide ittihaz olunmamış olması cihetiyle lisan-i mefkureyi tekellüme heves etmediklerinden Suriye ve Trablusgarb'a gidecek öğretmenlerin sıkıntı çekmemeleri için on talebenin Halep yahut Şam tarafına gönderilmesi oralarda ehl-i lisan ile ihtilat edilerek Arapça tekellüme alıştırmaları istizan kılındı."

Her iki proje de; Tanzimat döneminde yöneticilerin Arapça öğretimine bakış açılarının değiştiğini ve Arapça öğretecek ya da Arapça konuşulan bölgelerde görev yapacak öğretmenlerin yabancı dil ihtiyaçlarını doğru şekilde analiz ettikleri ve bu ihtiyaçların karşılanması yönünde etkin çözümler ürettiklerini göstermektedir. Bu yönüyle günümüz normlarına uygun bir yabancı dil öğretim vizyonu geliştirildiğini söyleyebiliriz.

\subsection{Dârülfünun ve Arapça Öğretimi}

31 Kânûn-1 Evvel 1863 (1280) yılında, Cemiyet-i İlmiye-i Osmaniye vasıtasıyla halka açık konferanslar şeklinde öğretim faaliyetlerine başlanmıştır. ${ }^{97}$ İlk konferanslar (ders-i âm), fizik, kimya, tabii bilimler, tarih, coğrafya alanlarıyla ilgili idi. ${ }^{98} 1282 / 1865$ yılında çıkan bir yangınla binasının tamamen yanması sebebiyle faaliyetleri kesintiye uğramıştır. ${ }^{99}$

1286/1869 Maarif-i Umumiye Nizamnâmesi’yle Dârülfünun kurulması fikri yeniden ele alınmıştır. ${ }^{100}$ Bu nizamnâmeyle Hikmet ve Edebiyat, Ulûm-1 Tabiiye ve Riyaziye ve İlm-i Hukuk şubelerinden meydana gelecek Dârülfünun-i Osmanî adıyla bir yüksek okul kurulması kararlaştırıldı. ${ }^{101}$ Şubelerin öğretim süresi üç yıl, öğretmen olacaklar için dört yıl olarak planlanmıştı. ${ }^{102}$ Dârülfünun 20 Şubat 1870 (1287) tarihinde yapılan törenle açıldı. ${ }^{103}$ Fakat kısa süre sonra faaliyetlerine ara verildi.

96 Özcan, a.g.m., s.446.

97 Koçer, a.g.e., s.76, 104; Unat, a.g.e., s.50; İhsanoğlu, a.g.e., s.323; Cemil Bilsel, İstanbul Üniversitesi Tarihi, İstanbul: İstanbul Üniversitesi Yayınları, 1943, s.13.

98 Unat, a.g.e., s.50; İhsanoğlu, a.g.e., s.323; Akyüz, a.g.e., s.147; Enver Koray, Türkiye'nin Çağdaşlaşma Sürecinde Tanzimat, İstanbul: Marmara Üniversitesi Fen Edebiyat Fakültesi Yayınları, 1991, s.108; Bilsel, a.g.e., s.13.

99 Ergin, a.g.e., s.553; Mustafa Ergün, II. Meşrutiyet Devrinde Eğitim Hareketleri (1908-1914), Ankara: Ocak Yayınları, 1996, s.26; Akyüz, a.g.e., s.147.

1001869 Maârif-i Umûmiye Nizamnâmesi, 79-128. maddeler.

101 Unat, a.g.e., s.50; Koçer, a.g.e., s.107; Ergin, a.g.e., s.553; Bilsel, a.g.e., s.14; Akyüz, a.g.e., s.147.

102 Akyüz, a.g.e., s.147; Bilsel, a.g.e., s.14.

103 Akyüz, a.g.e., s.148; İhsanoğlu, a.g.e., s.324. 
1291/1874 yılında Galatasaray Sultanîsi içinde Dârülfünun-i Sultanî adıyla üç şubeli olarak tekrar açılmıştır. a) Hukuk Mektebi b)Turuk ve Meabir Mektebi c)Edebiyat Mektebi ${ }^{104}$ Öğretim dili Türkçe ve Fransızca idi. ${ }^{105}$ Faaliyetlerine 1299/1881 yılına kadar devam edilen Dârülfünun'da bu tarihten sonra yüksek sınıflarının ayrılmasıyla öğretim tekrar durmuştur. ${ }^{106}$ II. Abdülhamid'in yirmi beşinci cülus yıldönümüne tesadüf eden 31 Ağustos 1900 (1318) tarihinde Edebiyat ve Hikmet (felsefe), Ulûm-1 Riyaziye ve Tabiiye (funûn) Şubesi ve Ulûm-1 Aliye-i Diniye (İlahiyat) şubesinden oluşan üç fakülteli Dârülfünun-1 Şahâne kurulmuştur. ${ }^{107}$ Eğitim süresi ilahiyat bölümünde dört yıl olup diğer şubelerde üç y1ld1. ${ }^{108}$ Edebiyat şubesinde haftada iki saat "Edebiyat-1 Arabiyye" dersi okutulmuştur. ${ }^{109}$

Dârülfünun'un sadece edebiyat şubesinde Arapça öğretimi vardı. Bu şubenin her üç sınıfına haftada ikişer saat "Edebiyat-ı Arabiyye" dersi konmuştur. ${ }^{110}$ 1332/1913 yılında Emrullah Efendi'nin bakanlığg esnasında yapılan ıslahat çalışmaları kapsamında oluşturulan yeni programla, Ulûm-1 Şeriye ve Ulûm-1 Edebiye şubesine haftada altı saat "Edebiyat-1 Arabiyye" dersi konmuştur. ${ }^{11}$

\section{6. Özel Okullarda Arapça Öğretimi}

Arapçanın özel okullarda öğretimine örnek verilecek en güzel uygulama, Hacı İbrahim Efendi'nin 4 Aralık 1883'de(1301) İstanbul Fatih’te açtığı ve "Dâru't-Talim" adını verdiği özel okuldur. Dâru't-talim iptidai ve rüşdiye kısmı bulunan özel bir okul idi. ${ }^{112} \mathrm{Hac}$ İ̉rahim Efendi’ye göre mevcut sistemdeki kusur yöntemdeydi. Dil öğretimi, Avrupa'da olduğu gibi yapılmalıydı. Ona göre; önce kendi dilimizin kurallarından olan Arapçayı tümüyle öğrenmeli, ondan sonra Fransızca hatta Rumca ve Ermenice de öğrenilmelidir. Tasrif isimli eserinin gayesini belirttiği önsözünde, Arapçanın Türkçeye yardımcı olduğunu söyler ve Arapçanın bilinmesi gerekliliğini kendi sözleriyle şöyle ifade eder. ${ }^{113}$

“...şimdi insaniyetle kemalimize bais olan lisanımızın şive ve edası Türkî ve onun mütemmim ve mükemmili Arabî' dir. Lugatın cümlesini bildiğimiz cihetle Türkî’ de biz selîkî olduğumuzdan anın kavâidini teallüme çendan ihtiyacımız var ise de Arabî'nin kavâid-i tasrîfiyesini teallüme şedîden muhtacız. Zira kavâid-i mezkûreyi bilmeyince bir lafz-1 Arabîyi, kastettiğimiz manayı ifade etmek için emsile-i muhtelifeye tahvîl etmeliyiz."

104 İhsanoğlu, a.g.e., s.325; Akyüz, a.g.e., s.148; Unat, a.g.e., s.51-52; Koçer, a.g.e., s.134.

105 Unat, a.g.e., s.53; İlhan Tekeli ve Selim İlkin, a.g.e., s. 72.

106 Akyüz, a.g.e., s.148; Unat, a.g.e., s.53; Bilsel, a.g.e., s.23.

107 İhsanoğlu, a.g.e., s.328; Unat, a.g.e., s.54; Koçer, a.g.e., s.143-146.

108 İhsanoğlu, a.g.e., s.328; Akyüz, a.g.e., 206.

109 Mehmet Ali Ayni, Darulfunun Tarihi, İstanbul: İstanbul Darulfünunu, 1927, s.33.

110 Ergün, a.g.e., s.261.

111 Ayni, a.g.e., s.36; Ergün, a.g.e., s.270.

112 A. Turan Arslan, "Hacı İbrahim Efendi ve Daru't-Talim Müessesi”, İlmi Araştırmalar, sy. 7, İstanbul 1999, s.38.

113 Arslan, "Hacı İbrahim Efendi", s.36-37. 
İbrahim Efendi Arapçanın kolayca öğretilmesi için yapılması gerekenler hakkındaki görüşleri şöyledir: ${ }^{114}$

“...Şöyle ki şakirdlerin sinni on ikiden yirmiye kadar olmalı ve şakirdlerin hiç Arabî kavâidesi görmeyip yalnız gazetelerdeki eşkâl-i kelimâtı okuyabilecek kadar olanlar için üç, ve mekteplerin usûlü üzere kavâid-i Arabî görmüş olanlar için iki sene müddet tayîn olunmalıdır. Biz de bu müddetlerin hitâmına değin beher gün o şakirdlerin ta'lîmlarine nezâret etmeliyiz."

İbrahim Efendi’nin Arapçanın tam olarak öğretilmesi için asgari iki yılı gerekli görmesi, günümüzde Arapça öğretimi yapılan dil kurslarında ve hazırlık sınıfı uygulamalarında değerlendirilmesi gereken bir tespittir. İbrahim Efendi, Arapça öğretiminde uyguladığı metodun diğer kurallarını şöyle belirtmektedir; yukarıda ifade edilen öğretim süreçlerinde, “öğrenciler yatılı bir mektepte bulundurulmalı ve başka bir ders okutturulmayıp öğretimleri yalnız Arapçaya ayrılmalıdır. Diğer derslere Arapçadan diploma almaya hak kazandıktan sonra geçmelidir." 115 Dönemindeki diğer özel okullara göre en önemli özelliği, bu okulda Arapçaya önem ve öncelik verilmesi, diğer derslerin ise Arapçada belli bir seviye ulaşıldıktan sonra okutulacak olmasıdır. Dil öğretimindeki hedefi şöyle belirlemişti: ${ }^{116}$

“...müteallime iki, üç senede ulûm-1 Arabiyyenin ciddi bir surette yani gördükleri ibarat-1 Arabiyyeyi hele Arabiyu'l-ibare olan gazeteleri halletmek ve tercüme eylemek mertebesinde bir melekeye gelmesini temin eylemektir."

\section{Dâru't-ta'lîm'de Arapça Dersleri ve Öğretim Usûlü}

Hacı İbrahim Efendi tarafından, Dâru't-ta'lîm mektebi için hazırlanan talimatnâmeye göre bu okullardaki öğretim metodu şöyleydi:

"Her öğretmen, sabahleyin okuttuğu ders eğer sarf ve nahivden ise öğrencilere dersi tekrar ettirerek her birinin hatalarını düzeltecektir. Hatasız okuyabilecek seviyeye gelene kadar okuma çalışmasına, ikinci teneffüse kadar devam edilecek, geçmiş derslerden dahi sorular sorularak müzakere yapılacak ve öğrencinin pratik beceri kazanması sağlanacaktır. Ders sarf veya nahiv dersinin dışında Edebiyat-1 Arabiyye ve Osmaniyyeden ise dersleri tekrar ettirmekle beraber fazla vakit kaybetmeden edebi metinlerin ve derste geçen önemli yapıların tercümesiyle onları meşgul edecektir. Sarf ve nahiv okuyan öğrenciler okudukları dersleri ezberlemekle mükellef olduklarından, ertesi günü derslerini öğretmene öğrendikleri konuları ezberden okuyacaklardır.”117

Bu talimattaki Arapça sarf ve nahiv öğretiminde iki önemli uygulamanın altını çizmek yerinde olacaktır. Birincisi; sarf veya nahiv dersinde geçen konunun, öğrenciler tarafından okunmasıdır. Hatasız okuma, kuralı olan bu uygulama esnasında, her öğrenciyle öğretmen birebir çalışıyor, karşılaşılan hatalar anında izah edilerek gideriliyordu. İkinci önemli nokta ise; öğrenciden gramer açısından tahlil edilmiş konunun ezberlenmesi isteniyordu.

114 Arslan, "Hacı İbrahim Efendi", s.39.

115 Arslan, "Hacı İbrahim Efendi", s. 39; Bildirici, a.g.e., s.85.

116 Arslan, Mehmed Zihni Efendi, s. 40.

117 Arslan, "Hacı İbrahim Efendi", s. 41. 
$\mathrm{Bu}$ ezber çalışması öğretmenin huzurunda tekrar ediliyordu. Böylece konu hem okuma anlama becerisini, hem de konuşma becerisini geliştirecek bir şekilde ders malzemesi haline getirilmiş oluyordu. Bu okuldaki Arapça öğretiminin başarı sebeplerini bizzat Hacı İbrahim Efendi şöyle açıklamaktadır:

“...Her şeyin esbabı olduğu gibi bu çocukların Arabîde terakkî etmelerinin dahi sebepleri vardır: Birincisi kavâid-i sarfiyye ve nahviyeyi Türkî lisan üzerine okuyup layıkıyla ve etrafiyla anlamaktır. İkincisi; mektebe duhûllerinden bu ana değin kamusu ellerinden bırakmayıp lugat-1 Araba intisap etmeleridir. Üçüncüsü; edebiyat-1 Arabiyyeden iki binden ziyade beyt ve kutub-i edebiyye ve tarihiyeden bin sahife kadar terkip okumalarıdır. Ve her birisi mütdet-i tahsillerini yalnız Arabîyeye hasreyleyip bu dereceye gelinceye kadar başka bir fen okumamalarıdır ...Buradan sonra bu sınıf talebeye münhasıran Arabî talim edilmeyip Arabînin ilm-i beyânı ile beraber Türkçe inşa ve kitabet ile Farisî talim olunacaktır." "118

Hacı İbrahim Efendi'nin uyguladığı yöntemin temel prensipleri şunlardır:

1. Öğrenciler yaşları 12-20 arasında ve sınıflardaki öğrenci sayısı ortalama 20 olmalı.

2. Arapça öğretimine tahsis edilen sürede başka dersler okutulmamalı.

3. Kavâid-i sarfiyye ve nahviyeyi Türk lisanı üzerine okuyup layıkıyla ve etrafiyla anlamalı.

4. Arapçadan Türkçeye ve Türkçeden Arapçaya tercüme çalışmaları yapılmalı

5. Çok yüklü ve yoğun okuma çalışması yapılmalı.

6. Öğrenciye sözlük kullanımının öğretilmeli.

7. Öğrencilere öğrendikleri gramer kaidelerinin tatbikatı yaptırılmalı.

8. Öğrenciler üzerinde ciddi bir motivasyon uygulanmalı. Öğrencilerin çeşitli tercüme denemelerini ihtiva eden "Asâr-1 Edebiye" adlı bir dergi çıkartılmıştır.

9. Arapça öğretimi tamamlandıktan sonra, diğer ilimlerin öğretilmesinde Arapça yazılmış kitaplar kullanılmalı.

\section{Tanzimat Döneminde Açılan Yeni Okullarda Arapça Öğretiminde Kullanılan Bazı Kitaplar ve Metodik Analizleri}

Osmanlı Devleti’nin yeniden kalkınmasının hedeflendiği Tanzimat dönemi, diğer alanlarda olduğu gibi Arapça öğretimi alanında da yenilik arayışlarının başladığı ve uygulamaya geçirildiği bir dönem olmuştur. Kısıtlı imkanlar ölçüsünde yeni okullar imparatorluk sathına yayılmaya çalışılmıştır. Bu okullaşma sürecinin önemli girişimlerinden biri de, Arapçanın yeni usüllerle daha etkili öğretilmesi olmuştur. Uygulanmaya çalışılan yeni usüllerin temel unsurlarından biri, bu metoda uygun kitaplar hazırlamaktır. Makalenin bu bölümünde Arapça sarf ve nahiv kurallarının öğretiminde yukarıda sözü geçen yöntemlere örnek teşkil edecek bazı kitaplar seçilerek incelenerek, böylece Arapça öğretimindeki yeni öğretim anlayışının özellikleri, metodik karakteri ve bunların gelişimi ortaya çıkarılmaya çalışılacaktır. Arapça öğretmek üzere hazırlanan belli başlı eserler incelenerek, metot bakımından analizleri yapıldığında Tanzimat

118 Arslan, "Hacı İbrahim Efendi”, s. 41. 
Dönemi'nde dilcilerin, Arapça sarf-nahiv kitapları hazırlarken dört ayrı metot izledikleri ortaya çıkmıştır. Bu dört ayrı metodu örnekleriyle şöyle sıralanabilir:

\subsection{Klasik Eserleri Yeniden Düzenleme Yöntemi:}

$\mathrm{Bu}$ yöntemde; müelliflerin Arapça öğretiminde medreselerde kullanılan Emsile, Bina, Maksud, Avamil, İzhar gibi klasik eserlerin üzerinde yaptıkları muhtelif çalışmalardır. Bazıları bu eserleri özetlemişlerdir. Mesela; Köse Efendi'nin yazmış olduğu Emsile Şerhi (İstanbul, 1311) gibi. Bazıları ise bu klasik eserleri kaynak olarak kullanarak, soru-cevap çalışması gibi farklı usullerde yeni kitaplar hazırlamışlardır. Mesela; Sualli Cevaplı Tertip Cedid Emsile, Hüseyin Hıfzı, (İstanbul, 1328). Bazıları da bu klasik eserlerin birçoğundan istifade ederek kendisinin düşünüp geliştirdiği projelerin kitaba dönüştürülmesinde klasik eserlerin hazırlanma tarzını benimsemiştir. Mesela; İbrahim Şemseddin, kaleme aldığı eserinin önsözünde kitabını Avamil tarzında ve ilaveli olarak hazırladığını dile getirmektedir. ${ }^{119}$

\section{Örnek Kitap: Arapça Yeni Sarf ve Nahiv (İkinci Kısım), ${ }^{120}$ Kitabın Metodik Analizi}

Kitabın kapağında şu bilgiler mevcuttur:

"tedrîsât-1 askeriye kitaplarından numara-2 Osmanlıcadaki Arapça kelimeleri terkipleri şakirdanın seviye-i idrâk ve derece-i tahsîline göre kolay ve esaslı bir tarzda gösterir ve Arapçaya alıştırır. Husûsen lisan-1 fen ve edebe geçmiş, zebânzed olmuş mevâk1 ${ }^{`}-1$ ihtirâma tâlik edilmiş hükm-i ahlakı, edeb-i ehadis-i şerifeyi, kelam-1 kibârı, darb-1 meselleri doğru okutup anlatır.

Esas i'tibâriyle terbiye ve tedrîsât-1 askeriye müfettişi umumiliğince tasavvur ve kabul olunan usule muvafik olmak üzere Kuleli ve Beşiktaş mekteplerinde muallim Hocazade A. Cevdet Efendiye yazdırılmıştır.”

Yukarıdaki malumattan ortaya çıkan en önemli bilgi, "Tedrisât-1 Askeriye Müfettişliğince" bir kurum olarak, Arapçayı daha kolay öğretmek üzere bir strateji benimsenmiş olması ve "kolay ve esaslı tarzda" uygulanabilecek bir yöntemin prensiplerine uygun doküman hazırlatılması yoluna gidilmiş olmasıdır. Kitap bu kurumca belirlenen ve kabul edilen usûle uygun olarak hazırlanmıştır. Kitabın iç sayfasında "Tarz-1 tedrîs" başlığı altında hazırlanan talimatlar bize uygulanan öğretim usulü ile ilgili kıymetli bilgiler vermektedir:

1. Her konunun cevapları, konunun sonundaki nazari suallere uygun olarak öğretilecek, tahtaya misaller yazılarak bu misaller için gerekli açıklamalar yapılacak.

2. Uygulama ve alıştırma cümlelerinin Türkçelerini öğretmenler söyleyecek, öğrenciler defterlerine yazacak daha sonra öğretmen cümlelerin doğru şekillerini tahtaya yazarak öğrencilerin hatalarını düzeltmesini isteyecek.

119 İbrahim Şemseddin, Nahv-i Arabî, İstanbul: Arif Efendi Matbaası,1317.

120 A. Cevdet Hocazâde, Arapça Yeni Sarf ve Nahiv (İkinci Kısım), İstanbul, Mekteb-i Harbiye Matbaası, 1323. 
3. Uygulama kısımlarında cümlelerden gramer açısından gerekli olanlar tahtaya yazılacak ve gerekli açıklamalar yapılacak.

4. Sarf ve nahiv tahlilleri kitabın sonundaki örneklere göre yaptırılacak, öğretmenin verdiği tahlil ödevleri öğrenciler tarafından yapıldıktan sonra doğru şekilleri tahtaya yazdırılacak, öğrenciler tahtadakilere göre defterlerine yazdıkları cümleleri tashih edeceklerdir.

5. Fiiller, önemli sarf bilgilerindendir. Birinci bölümde tamamen öğrenilmiş olacağından, ikinci kısımda fiillerin tatbiki olarak kullanılmasına özen gösterilecektir.

Müellifin önsözünde, kitabın muhtevası ile alakalı olarak yer alan bilgiler şunlardır; $\mathrm{Bu}$ kitabın yazılmasından amaç, öğrencilerin Osmanlıcada kullanılan Arapça lafızlar ve terkiplere vakıf olmalarını sağlamaktır. Ayrıca öğrencilerin yaşı ve tahsil durumlarına göre Arapçaya tam olarak vakıf olabilmeleri için kelimelerin tatbikatıyla öğretilmesi gereklidir.

\section{Örnek Dersin Metodik İncelenmesi}

Ders olarak işlenecek konular “ders ve numarası” şeklinde sıralanmıştır. Dersin bitiminde konuyla ilgili "tatbîkât", "mumarese" ve "temrîn" çalışmaları hazırlanmıştır. Bazı önemli derslerin sonunda "nazarî suâller" başlığı altında dersle ilgili nazari bilgilerin sorgulandığı sorular hazırlanmıştır. Örnek ders olarak birinci dersi ele alalım: ${ }^{121}$

\section{Ders - 1}

\section{Fiil}

Ta 'rîfi - başlı başına manası olmakla beraber geçmiş şimdiki gelecek zamanlardan birini bildiren kelimeye (fiil) denir.

$$
\begin{aligned}
& \text { قعد = oturdu, } \quad \text { = يكتب = yazar, yaziyor } \\
& \text { gelecek }
\end{aligned}
$$

Envâ'-1 fi'‘ (mâzi, muzari, hâl, istikbal, emr ) namıyla beş türlüdür.

Fi'l-i mâzi

Ta'rîfi - Bir işin geçmişte olduğunu bildiren fiile, fi'l-i mâzi denir.

Teşkîli- fi‘'l-i mâzi mastardan zâid harfleri atılarak yapılır. Müfred müzekker gaib sigâsı esas ittihâz edilir diğer sigâlar müfred müzekker gaibe bir takım müntehâ (son ek) ilavesiyle meydana gelir.

Mâzinin müfred müzekker gaibi; ehl-i lisanın kullanışına göre ( فُعلَ ، فعِلَ ، فعلَ ) şeklinde kullanılır"

Yukarıdaki şekilde teorik bilgileri verdikten sonra, örnek fiiller mâzi fiile eklenen son ekler teferruatlı bir şekilde izah edilmiştir. Daha sonra aksam-1 seb 'adan her birine örnek teşkil eden fiillerin on dört sigâsının anlamı verilerek çekimi yapılmıştır. Bu tafsilatlı çalışmadan sonra dersler ilgili temrînât safhasına geçilmiştir. Önce "tatbîkât" başlı̆̆ı altında, içinde mâzi fiiller bulunan çeşitli uzunlukta cümleler toplanmıştır. Kitabın başında verilen talimata uygun olarak

121 Hocazâde, a.g.e., s.3-12 
“tatbîkât” derslerinde geçen cümleler tek tek öğrencilere tahtada yazdırılacak, gerekli açıklama ve düzeltmeler örnek cümle üzerinde çalışılacak ve defterlere yazdırılacaktır. Örnek dersimizde mâzi fiiller ile ilgili alınan yaklaşık 20 örnek cümleden bazıları şöyledir: ${ }^{122}$

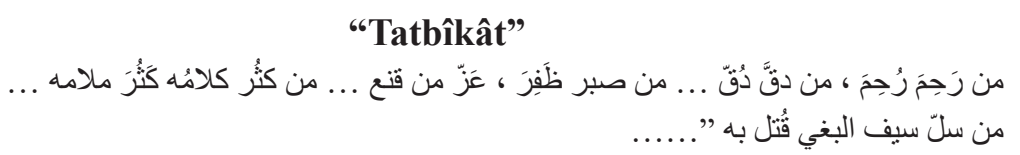

Her derste "tatbîkât" kısmından sonra "mumârese" kısmı yer almaktadır. Bu kısımda baş tarafta verilen özel ta 'lîmâta uygun olarak talebeden verilen örnekler üzerinde mumarese (pratik) yapması istenmiştir. Örnek dersimizin mumârese kısmını inceleyelim: ${ }^{123}$

$$
\begin{aligned}
& \text { "Mumârese" }
\end{aligned}
$$

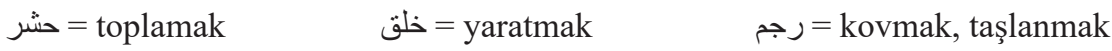

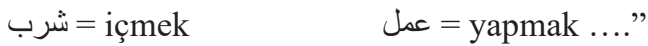

Mumaresede verilen yaklaşık 20 mastarın mâzi formu elde edilerek, mâzi sigâsında çekimi istenmektedir. Mumarese kısımlarını "temrîn” kısımları takip etmektedir. Temrîn kısımları da mumârese kısımlarında olduğu gibi özel bir talimatla başlamakta ve öğrencilerin özel bir çalışma yapması talep edilmektedir. Böylece talebenin dikkati ve üretme becerisi, konunun özüne yoğunlaştırılmakta ve ezberden ziyade bilinçli bir öğretim uygulanmaktadır. Örnek dersimizin temrîn çalışmasını bir bölümü inceleyelim: ${ }^{124}$

\section{"Temrîn"}

Aşağıdaki mâzilerin hangi mastardan alındığını, müfred müzekker gaibi ne şekilde olduğu, hangi şahsı bildirdiği beyan edilecek.

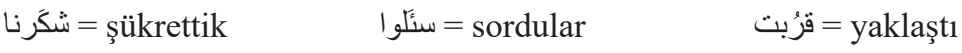

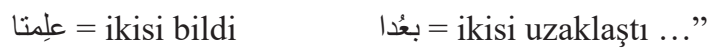

Yaklaşık 20 fiilin çeşitli şahıslara göre çekimi yapılmış olarak verilmiş ve bu fiillerin yukarıdaki malumât çerçevesinde çalışılması istenmiştir. Mâzi fiiller dersinin en sonunda, bu dersle alakalı nazari bilgilerin sorgulandığg soruların yer aldığı "Nazari suâller" bölümü yer almaktadır.

\section{"Nazari suâller"125}

"Fiil nedir, fiil kaç türlüdür, fi'l-i mâzi neye denir, nasıl bilinir, fi'l-i mâzi kaç sigâdır, muhtevası hangi lafizlardır, bunlar neye mahsustur, fi'l-i sahihten, mehmuzdan, misalden nasıl tasrîf olunur, ecvefden ne şekilde tasrîf edilir, nâkıs ve lefifden nasıl tasrîf olunur ..."

122 Hocazâde, a.g.e., s.12

123 Hocazâde, a.g.e., s.13

124 Hocazâde, a.g.e., s.13

125 Hocazâde, a.g.e., s.14. 


\subsection{Avrupa'da Ortaya Çıkan Dil Öğretim Yöntemlerini Arapçaya Uyarlama Yöntemi}

Müellifler, Avrupa'da ortaya çıkan dil öğretim yöntemleri prensiplerini hiç değişiklik yapmadan birebir uygulayarak, Osmanlı Devleti okullarındaki Arapça öğretimi hedeflerine uyarlamışlar ve Arapça öğretim alanında ilk defa kullanılan kitaplar hazırlamışlardır. Örnek kitap: Maarif Nezareti'nin talimatıyla oluşturulan üç kişilik bir komisyon tarafından hazırlanan Talimu'l-Lugati'l-Arabiyye ala Tarikat-ı Berlitz adlı eser, bu tür kitaplar için en güzel örneği teşkil etmektedir. Eserde Berliç Yöntemi diye bilinen öğretim yöntemi kuralları Arapça öğretimine uyarlanmıştır.

\section{Örnek Kitap 1: Ta'limu'l-Lugati'l-Arabîye a'lâ Tarîkat-ı Berlitz ${ }^{126}$ Kitabın Metodik Analizi}

Kitabın kapağında: "Mekâtib-i Sultanîyenin altıncı ve yedinci senelerinde tedrîs edilmek üzere..." ifadesi yer almaktadır.

Kitap iki kısımdan oluşmaktadır: Birinci kısmı "Kısmu'l-Müfredat ve Cümel”"27 İkinci kısmı ise "Kısmu'l-kırâa"128 oluşturmaktadır.

Birinci kısımda yer alan onbeş ders ${ }^{129}$, Sultanî altıncı sınıfta okutulmak üzere hazırlanmıştır. Onbeşinci dersin bitiminde “ دروس السنة السابعة (Yedinci sene dersleri)” "130 başlığılyla yedinci seneye ait dersler başlamaktadır. Okuma kısmında "altı ve yedinci senelerde müşterek" ifadesi vardır.

Birinci kısma ait derslerin tanzimi Berliç Usûlüne uygun olarak hazırlanmıştır. Talebelerin yakın çevresinde bulunan eşyaların resimleri kullanılmıştır. Resimlerin hemen altında Arapça ismi yer almıştır. Sınıfta, evde kullanılan malzemeler, vücut azaları, hayvanlar, ulaşım vasıtaları gibi ders konusu olarak seçilen kavramlar önce resimlendirilmiş̧ir. Resimsiz olarak düzenlenmiş bazı dersler de bulunmaktadır.

Kitabın mukaddimesinde Berliç Usûlü detaylı bir biçimde anlatılmıştır: Bu ifadelere göre yabancı dilleri öğretmek için eskiden beri takip edilen çeşitli usullerin yetersiz olmaları nedeniyle Arapçanın dil olarak öğretilmesi hedefi gerçekleştirilememiştir. Maksadın hasıl olamaması, gereksiz zaman kaybına neden olmuştur. Bunları dikkate alan batılılar tarafından yapılan tecrübelerin bir neticesi olarak dil öğretimiyle ilgili çeşitli usüller ortaya çıkmış ve birçok kitap yazılmıştır. Öğretilmek istenen dilin tam bir şekilde öğretimini, en kısa zamanda temin etmek gayesiyle dilciler, yeni yöntemler arayışlarına girmiştir. Almanyalı öğretmen Berliç'in

126 Galata Sultanîsi Edebiyat Muallimi Ali Suad, el-Hedaya dergisi kurucusu ve el-Hilal el-Osmani gazetesi sahibi Abdülaziz Caviş, İstanbul Sultanîde Arapça Muallimi Edhemzade Muhammed Kemaleddin, Ta 'limu 'l-Lugati'lArabîye a 'lâ Tarîkat-ı Berlitz, İstanbul: Mahmud Bey Matbaası, 1331.

127 Komisyon, Ta'limu'l-Lugati'l-Arabîye a 'lâ Tarîkat-ı Berlitz, İstanbul: Mahmud Bey Matbaas1 1331, 13-132.

128 Komisyon, Ta'limu'l-Lugati'l-Arabîye a 'lâ Tarîkat-ı Berlitz, 133-190.

129 Komisyon, Ta'limu 'l-Lugati'l-Arabîye a'lâ Tarîkat-ı Berlitz, 13-74.

130 Komisyon, Ta'limu'l-Lugati'l-Arabîye a'lâ Tarîkat-l Berlitz, 75-132.

131 Komisyon, Ta'limu'l-Lugati'l-Arabîye a'lâ Tarîkat-ı Berlitz, 133. 
ortaya koyduğu yöntem diğerlerine göre daha üstün bulunmuş ve birçok ülke tarafından kabul edilmiştir. Bunları nazar-1 dikkate alan Maarif Nezareti Arapça'nın kısa bir müddet içinde ayrıca bir lisan olarak öğretimi için adı geçen usulü kabul etmiştir. Mekteplerin seviyesi ve talebelerin yaş durumu dikkate alınarak Arapça öğretimi iki yıla taksim edilmek üzere Berliç usulüne uygun olarak bir kitap hazırlanmasını uygun bulmuştur. Böylece bu usulle mekteplerimizde Arapçanın müstakil bir dil olarak öğretimi mümkün olacaktır.

Berliç usulünün esası, bir dili görünen eşyaları ve bilinen manaları ezberlettirmek, bunları cümleler ve hikayeler şeklinde tekrar ve tatbik ile hafizaya nakşetmektir. Bu işlemin dilin fesahatine ve kurallarına uygun olarak yapılması esastır. Bu maksada ulaşmak için, öğrencinin daima gördüğü eşyalar ve fikrinin alışık olduğu manayı tekrarlayarak öğrenmesi esastır. Mesela; okulda daima gördüğü ve kullandığı eşyalar, evinde bulunan ve sokakta karşılaştığı insanlar, tabiatta daima gördügü manzaralar ile bunlara delalet eden isimler, sıfatlar, fiiller ve ibarelerin bir konu etrafinda tatbik edilerek ve bunlar arasındaki bağlantılara binaen değişik manalar içeren ibareler ve cümleler oluşturmak hedeflenmiştir. Bu konuda Muallim Berliç'in derslerin tatbikatıyla ilgili olarak kitabın birinci kısmı için koyduğu bazı kuralları dikkate almak yöntemin icrası için önemlidir:

1. Dersin ilk yarısında öğretim usulü dinleme çalışması şeklinde olmalıdır,

2. Öğretmen evvela, öğreteceği kelimeleri düzgün ve açık bir uslupla telaffuz ederek öğrencilere dinlettirmelidir. Kelimenin delalet ettiği anlamı işaretle veya müşahhas bir şekilde anlatmalıdır. Talebenin tam olarak anladığı kanaati hasıl olunca diğer kelimelerin izahına geçmelidir.

3. Başlangıçta az miktarda kelime almalı ve bunları "evet, hayır, uzun, kısa, siyah, beyaz, çok, az, bazıları, hiçbiri ....” gibi muhtelif sıfat ve durumlar içinde her biriyle karşılaştırmalı olarak “almak, taşımak, çıkmak, görmek, bilmek...” gibi fiillere tatbik etmeli ve bu surette öğrencinin zihninde birbirine zıt veya muvafik durumlar oluşturarak bu kelimelerin manasını iyice anlatmalıdır.

4. Talebeleri dili kullanmaya tam manasıyla alıştırmak için misalleri çoğaltmalı, içinde bulunulan duruma veya görülen şeylere göre kitapta bulunan örnekler tadil edilmelidir fakat bu dersin seviyesine ve sinıf durumuna uygun tarzda yapılmalıdır.

Dersin ikinci yarısında kelime ve cümleleri okumalı sonra talebeye okutmalıdır. Talebeler, o dersteki kelimelerin hepsini öğretmen yardımına muhtaç olmaksızın okuyacak hale gelinceye kadar okuma faaliyeti devam ettirilmelidir.

Kitabın ikinci yani okuma kısmında uyulacak kurallara gelince;

1. Öğretmen önce, konuyu kâfi derecede anlatarak tam bir hüküm içerecek miktarda birkaç cümleyi okur. Sonra okunan kısmı öğrenci tekrar eder. Telaffuz hataları varsa bunlar öğretmen tarafından düzeltilir.

2. Öğretmen, okunan kısımla ilgili birçok soru sorar. Bu soruların okunan kısımla ilgili olmasına dikkat edilmelidir. Geçen kelimeler üzerinde ne kadar çok soru sorulursa öğrenci o kadar çok gelişme kaydeder. Öğrenci eğer cevapta tereddüt ederse öğretmen 
cevabı üretebilmesinde ona yardımcı olacak miktarda yardım edebilir. Eğer talebe soruya yine cevap verememişse muallim ısrar etmemelidir. Çünkü bu durum öğrencinin zihnini boş yere yormaktan başka bir fayda vermez. Böyle bir durumda ya o suali o esnada büsbütün terk etmeli ya da daha kolay suallerle dolaşarak, tedricen önceki suale gelme usulü takip edilmelidir.

3. Ders esnasında önceden bahsi geçmemiş yeni bir fiille karşılaşıldığı zaman öğretmen o fiilin muzarisini tahtaya yazar daha sonra çeşitli sorular ve cevaplarla o fiilin muhtelif şahıslarını talebeye söyletir.

4. Her ders bir kere okuma ve konuşma ile iyice tatbik edildikten sonra talebe onu ezberlemelidir.

5. Manaları, mücerred (= soyut) olan fiilleri tek başlarına kullanmayarak onları bir cümle içinde tatbikatıyla öğretmelidir. Bu fiillerin çeşitli zamanlarını aynı usulle başka kelimelere bağlayarak anlatmalıdır. Mesela (Bilmek) fiilini “ismimi bilir misiniz? İsmimi nereden biliyorsunuz? Bilir misiniz ki falan şey sizin odanızdadır? Cebimde kaç kuruş var bilir misiniz?” gibi muhtelif yerlerde söyleyerek anlatmalı ve yine muhtelif zamanları mesela "Bu adam niçin yorgundur? Çünkü çok yürümüştür. Haftada kaç ders alıyorsunuz? Geçen sene ders aldınız mı? Gelecek sene ders alacak mısınız?” gibi tatbîkât ile öğretmelidir. Bu dersler yukarıda açıklandığg gibi okuma ve diyalog olarak tatbik edildikten sonra, bir de muallim tarafından imlâ yoluyla yazdırılmak sûretiyle talebenin defterine geçmesi ve muallim tarafından kontrol edildikten sonra hıfz edilmesi lazımdir.

Bu derslerin yukarıda açıklandığı gibi okuma-anlama ve konuşma çalışmalarıyla tatbik edildikten sonra talebenin defterine yazması ve öğretmen tarafından kontrol edildikten sonra ezberlenmesi lazımdır.

Muallim Berliç'in yukarıdaki malumatı uzun süreli bir tecrübenin neticesi olmasından dolayı, ortaya koyduğu yöntemin faydalı ve verimli olabilmesi için uygulanacak öğretimde uyulması ve kuralların icrasının ihmal edilmemesi çok önemli görülmüştür. Berliç Yoluyla Arap Dili Öğretimi konusunda bu kitabı yazan komisyon üyeleri Ali Suad Galata Sultanîsi Edebiyat Muallimi, Abdülaziz Caviş (el-Hedaya Dergisi kurucusu ve el-Hilal el-Osmani gazetesi sahibi), İstanbul Sultanîde Arapça Muallimi Edhemzade Muhammed Kemaleddin'nin Arapça olarak verdikleri malumatın tercümesini buraya almayı uygun gördük:

"Dillerin meydana çıkma yolları şöyle gerçekleşmiştir; insanoğlu maksadını, çok zorluklar, sıkıntılar ve çok zaman kaybından sonra ifade edebilmiştir. Batılılar dillerini kolaylaştıracak şekilde ve kendi anlayışlarına göre yöntemler ve metodlar îcâd ederken, biz ise eskilerin eserlerine bağlı kalmaya devam ediyoruz. Evvelki alimler, kendi çabalarıyla dil öğretme metodlarını kolaylaştırmaya ve bu alanda kendi zamanlarının anlayışına uygun kitaplar ortaya koymaya çalışmışlardır. Lakin bizler onların bu gayretlerine uygun olarak hareket etmiyoruz. Biz de kendimizi onlara benzeterek yeni îcâdlar ortaya koyup onları takip edip geçemiyoruz. 
İşte bu yüzden günümüze kadar önemli bir dil olan Arap dili, ileri görüşlü talebelerden yoksun olarak gelmiştir.

Zorunlu bir ihtiyaç olarak eski metod değiştirilmeli ve tecrübelerle meydana çıkmış ve bu alanda çok mesafe kat etmiş, medeni milletlerin metodlarına uyum sağlanmalıdır. Alman Berliç Metodu, metodların en güzeli, en kolayı, en yenisi ve en meşhûru olarak meydana çıkmıştır.

Bugün Avrupa milletlerinden hepsi bu metoda tâbi olmuşlardır. Hatta bazı doğu milletleri de fâideleri meydana çıkmış olan bu metodu gördüklerinde kendilerine örnek metod olarak kabul etmişlerdir.

İşte bu yüzden Maarif Nezareti bu metoda önem vermiştir. Arap dilini Osmanlıca ana diliyle öğretme yoluna gitmeye karar vermiştir, tâ ki bu hedeflenen gaye gerçekleşebilsin. İşte o gaye de Kura'n-1 Kerim'in dilinin kısa bir zamanda diğer memleketlerde yayılmasıdır.

Maarif Nezareti çok değerli insanlardan müteşekkil bir heyeti, Berliç Metodu'nu kullanarak Arapça kitaplar serisini te’lîf etmek üzerine vazifelendirmiştir. Bu, o kitap serisinin ilkidir, Berliç metodunun meyvelerinin erken olgunlaşmış sonucudur. Bu kitap aynı zamanda fiilî öğretim örneğidir ki, öğretmene bu usûlün uygulanışını örnek olarak göstermede geniş bir imkân sunar.

Bu kitap, öğretmen Berliç'in dil öğretiminde koymuş olduğu asıl ve esaslara uygundur. Ama Berliç yöntemi ile eğitimin prensibi, öğrencilere dili kendi hayatı içine yaklaştırarak dilin fesahât ve i'rabı muhafaza etmekle beraber dil kâidelerinin tatbîki ve mumaresesi gibi metodlarla dili öğretmektir.

Bu metodla öğretmen, öğrencilerin nazarlarını hissedilen eşyalara çevirmeye başlar. Öğrencilerin dikkatleri eğitim odasında olur. Etraflarına bakarlar. Kalem, mürekkep, kâğıt, tahta, sandalye, kitap gibi eşyayı görürler. Veya nazarlarını vücud organlarına çevirirler. Onlara konuşmak için ne yapmak gerektiği söylenir. Bu hissedilen ve görülen isimlerle cümleler oluşturulur. Manevi isimler veya terkîpte yer alan fiiller siyâk ve karîne ile anlaşılır. Bu kelimelerin terkîp çeşitlerindeki isbâtı, nefyi, takrîri ve istifhâmı muallim ne kadar geniş ölçüde açıklarsa o derece öğrencinin zihninde yerleşir. Hafizasında güçlenir ve yavaş yavaş konuşmaya başlar. İstenilen şey budur. Öğretmen bunu uygulamayı, nesnelere işaret ederek tekrar tekrar yapar. Eşyaların isimlerini açık i'rablı bir telaffuzla ve kendinden uzakta olan birine hitap ediyormuş gibi duyuracağı bir sesle konuşmayı yineler. Öğrenciler bu kelimelere alışınca öğretmen mezkûr yöntemle farklı kelimeler ve cümleleri kurallarıyla açıklayarak anlatır. Şöyle ki: Öğretmen öğrencilere bir kitabı işaret ederek "bu bir kitaptır" der, sonra bir kaleme işaret eder ve "bu bir kalemdir" der, Sonra "bu nedir?" diye sorar. "Bu kitap mıdır? Bu bir kitap mı yoksa bir kalem midir? Kitap nerede? Kitap sandalyede mi?” Her soruda onlara nasıl cevap verileceğini öğretir. Aynı şekilde öğrencilere söylediği diğer kelimeleri de işler. Sonra onlara kendi cümlelerini üretmeyi teklif eder. Cümle kurma ve öğrendikleri kelimeleri kullanma çalışmasında ders amacına ulaşınca, öğretmen onlara ev ödevi verir. Sonra bunları düzeltir ve tekrar eder. Bunları özel bir deftere yazarlar.

Okuma derslerinin uygulaması şu şekildedir. Öğretmen öğrencilere bir okuma parçası okuyup ve temsîlî resme işaret ettikten sonra onların tek tek okumalarını ister. Sonra onlara 
parça hakkında sorular sorar. Seçtiği bir öğrenciden özetlemesini ister. Ezber bölümüne gelince öğretmen onlara kitabın ilgili bölümünden bir parça veya bir manzûmeyi usûlünce okur, sonra vakit yetiyorsa, bazılarına onu yüzünden okumayı teklif eder. Sonra herkesin onu ezberlemesini ve belli bir süre içinde tek tek öğretmene okumalarını ister.

Güzel yazı öğrenmek için ise imlâ dersi gereklidir. Öğretmen onlara söylediği veya naklettiği şeylerden bazı parçalar yazdırır. Öğrenciler öğretmenden duyduklarını hareke ve sükunlarına göre temiz bir kâğıda yazarlar. Boş zamanda öğretmen onların yazdıklarını alır ve düzelttikten sonra iade eder. Öğrenciler bunu daha önce zikri geçen konuşma cümleleri ile beraber yazarlar. Öğretmen, zorunlu olmadıkça derste öğrettiği yabancı dilden başka bir dil kullanmaktan sakınmalıdır. Bu faydalı öğretme şeklidir..."132

\section{Bir dersin metodik incelemesi}

611. Ders" 133

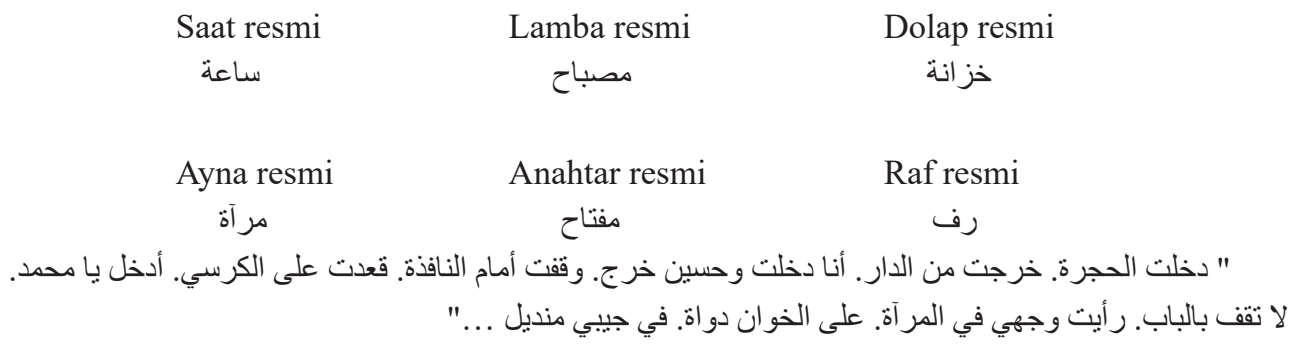

(Cümlelerin bitiminde bu cümlelerle ilgili sorular yer alır): ${ }^{134}$

$$
\text { من من دخل الحجرة؟ }
$$

Resimlerin altında resimlerle ilgili kelimelerin kullanıldığg kısa, sade ve özlü cümleler vardır. Sonrasında cümlelerle ilgili kısa kısa sorular bulunmaktadır. Altı ve yedinci sınıflarda müşterek olarak okutulan kısa parçalar yer almaktadır. Parçalar öğrencilerin ilgisini çekecek konulardadır. Mesela "aslan, tilki ve kurt, aslan ve iki öküz, insan ve hayvan, namaz, vatan, güvercin ve karınca, adam ve çocukları, Allah sevgisi...” gibi.

Kitabın sonunda " قسم الاستظهار (k1smu'l-istizhâr)"135 adıyla erdemlilikler içeren okumas1 ve ezberlenmesi kolay şiirler yer almaktadır.

132 Komisyon, Ta 'limu'l-Lugati'l-Arabîye a'lâ Tarîkat-ı Berlitz, önsöz.

133 Komisyon, Ta'limu'l-Lugati'l-Arabîye a 'lâ Tarîkat-ı Berlitz, 54.

134 Komisyon, Ta'limu'l-Lugati'l-Arabîye a 'lâ Tarîkat-ı Berlitz, 56.

135 Komisyon, Ta 'limu 'l-Lugati'l-Arabîye a 'lâ Tarîkat-ı Berlitz, 178-190. 


\section{Örnek Kitap 2: Usûl Tedrîs-i Arabî ( Mösyö (An) K Usûlünden müktebestir ) ${ }^{136}$ Kitabın Metodik Analizi}

Kitabın kapağında yer alan ifadesinden eserin, idadi mekteplerinde kullanılmak üzere hazırlandığı anlaşılmaktadır:

"Maarif-i Umumiye Nezareti Celilesi tarafindan Umum Mekâtib-i İdadiyenin birinci, ikinci ve üçüncü senelerinde tedrîs edilmek üzere intihab ve kabul buyrulmuştur"

Müellif eserini, Mösyö An K usûlünü esas alarak hazırladığını belirtmektedir. Bu ifade; Tanzimat döneminde, müelliflerin dil öğretim metotlarını araştırdıklarını ve bu metodlara uygun kitap hazırlama konusunda Avrupa'da ortaya çıkan usûlleri, yakından takip ettiklerini göstermektedir. Müellif Avrupalı bir dilcinin ortaya koyduğu yöntemin kaidelerini, Arap Dili’nin öğretimine uyarlayarak kitabını hazırlama gayreti içinde olmuştur. ${ }^{137}$

Kitap genel çerçevede üç ana bölüm üzerine binâ edilmiştir: Birinci bölümde ${ }^{138} 89$ Ders ve bu derslerle alakalı olarak verilmiş 87 Ta'lîm (alıştırma); İkinci Bölümde ${ }^{139}$ gramer kuralları verilmektedir. Üçüncü Bölümde ${ }^{140}$ ilki edatlar ve anlamlarının sıralandığı, ikincisi de kitapta geçen kelimelerin alfabetik olarak sıralandı̆̆ı iki sözlük yer almaktadır.

Bunları sırasıyla inceleyelim; Birinci bölümde "Dersler": Bu bölümde, 89 adet ders, tırnak içinde ve ders numarası verilerek sıralanmıştır. Her derste öncelikle bir kelime listesi verilmiştir. Kelimelerin veriliş tarzından, İdadi Mekteplerinde birinci sınıftan itibaren okutulacak olan bu kitabın, temel gramer öğrenimini tamamlamış olan öğrencilere okutulmak üzere hazırlandığını tespit etmek mümkündür. Çünkü kelimeler, isim, fiil, basit-zor ayrımı gözetilmeksizin verilmiştir. Fakat derslerin akışında basitten karmaşığa doğru tedrici bir usûlün var olduğunu söylenebilir. Kelime listesinin hemen altında kelimelerin kullanıldığı örnek cümleler, peş peşe satır sırası gözetilmeksizin sıralanmıştır. Örnek cümlelerle ilgili tercüme veya tahlil çalışması yoktur. Bu bölümden sonra bir başka derse geçilmektedir.

Bir veya iki dersten sonra, "Ta'lîm" adıyla bir bölüm yer almaktadır. Bu bölümde 10-15 arasında Türkçe cümle yer almaktadır. Ne tür bir alıştırma yapılmak istendiği konusunda açıklayıcı talimat yoktur. Fakat tahminen bu cümlelerin ya sınıf içinde uygulamalı tercüme çalışması ya da ev ödevi olarak Arapçaya çevrisinin istendiğini söylenebilir. ${ }^{141}$

\section{Örnek dersin metodik incelemesi}

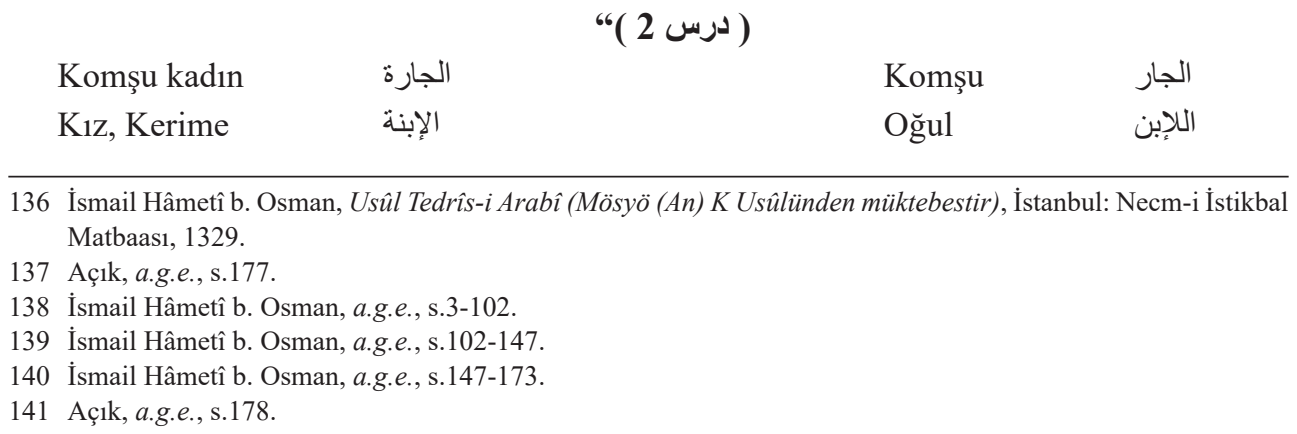




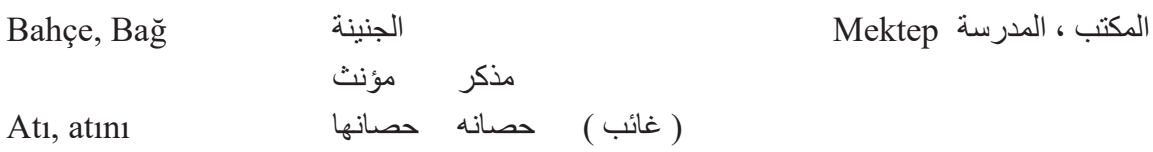

(Burada, tekil üçüncü şahıs bitişik zamirinin müzekker ve müennes şekli verilerek küçük bir gramer hatırlatması yapıliyor.)

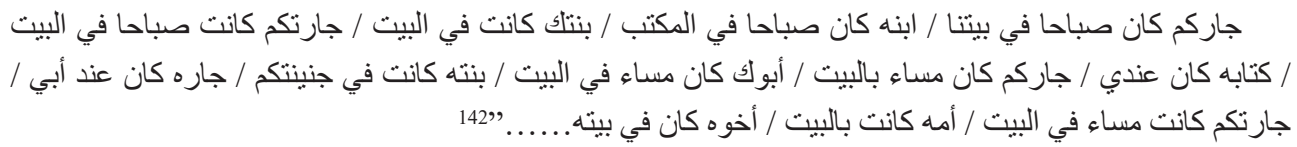

Örnek cümlelere baktığımızda ilk dikkat çeken özelliğin, cümlelerin daha önceki kitaplarda olduğu gibi, klasik ve klişeleşmiş örnekler değil, günlük yaşam ile alâkalı, öğrencilerin benzerlerini üretmelerine yardımcı olacak bir üslup içinde basit ifade ve yapıları içermiş olmalarıdır. Yani öğrenci bu cümleleri öğrendiği zaman, gerek bu cümleler, gerekse öğrendiklerinin yardımıyla kendi üreteceği cümleleri pratik olarak rahatça kullanabilecektir. Ayrıca cümlelerin belli bir konuda yoğunlaştığı ve o konu çerçevesinde aşağı yukarı bütün alternatif cümleleri içerdiği de görünmektedir. Mesela yukarıdaki derste en çok üzerinde durulan dilbilgisi kavramlar1; كانت / كان yardımc1 fiilleri, صباحا / مساء zaman zarflar1, بيتنا / بيتته / بيتكم / بيتها / aitlik bildiren bitişik zamirlerin kelimelerin sonunda kullanımı ile ilgilidir. ${ }^{143}$

Kitabın alıştırmalar kısmı; 87 "Ta'lîm” içermektedir. Her bir alıştırma kendinden önceki bir veya birkaç dersle ilgili Türkçe cümleler ihtiva etmektedir. Örnek olarak birinci alıştırmayı ele alalım:

\section{"Ta'lîm 1}

"Validen sabahleyin bizim evde idi. / Komşu kadın akşamleyin sizin bahçede imiş .... (Bu tür alıştırmalarda ortalama 10 adet cümle vardır)" 144

Alıştırmalar derslerde öğrenilen kelime ve gramer yapılarıyla uyumlu ve onları pekiştirir niteliktedir.

İkinci Bölümde "Kavâid-i Esasiye"145 başlığı altında gramer konuları incelenmiştir. Genel olarak konuların kısa ve özlü şekilde tanımı verildikten sonra, konu ile alakalı örnek cümleler ve Türkçe karşılıkları verilmiştir. Örnek cümle üzerinde tahlil çalışması yoktur.

Konuların incelenmesi sırasında en dikkate değer kısım, fiil zamanlarının verildiği kısımdır. ${ }^{146}$ Bu bölümde fiil zamanları incelenirken, Türkçe zamanlar esas alınarak onların Arapça karşılıkları da üretilmiş ve bunların tam çekimi verilmiştir. Öğrencinin ana dilindeki zaman kavramlarının hedef dildeki karşılıklarının verilmesiyle öğrenilen dil olgusunun öğrencinin zihninde ana dili bilgisiyle örtüşmesi sağlanarak zihne yerleşmesi hedeflenmiştir. Öğrencinin ana dilini

142 İsmail Hâmetî b. Osman, a.g.e., s.4.

143 Açık, a.g.e., s.179.

144 İsmail Hâmetî b. Osman, a.g.e., s.4.

145 İsmail Hâmetî b. Osman, a.g.e., s.102.

146 İsmail Hâmetî b. Osman, a.g.e., s.123-139. 
kullanma becerisi, yabancı dil öğreniminde yardımcı bir unsur olarak kullanılmıştır. Bu bilginin öğrencinin öğrendiği dili özellikle konuşma becerisinde pratik olarak kullanmasına yardımcı olacağı açıktır.

Örnek olarak "gelecek zamanın hikayesini”" şu şekilde tertîp edilmiştir: ${ }^{147}$

\begin{tabular}{|c|c|c|c|}
\hline & مؤنث & مذكر & \\
\hline Yazacaktım & كنت سأكتب & كنت سأكتب & متكلم (م) \\
\hline yazacak idik & كنا سنكتب & كنا سنكتب & (ج) \\
\hline yazacak idin & كنت ستكبين & كنت ستكتب & مخاطب (م) \\
\hline yazacak idiniz & كنتما ستكتبان & كتمما ستكتبان & (ت) \\
\hline yazacak idiniz & كنتن ستكتبن & كنتم, ستكتبون & (ج) \\
\hline yazacak idi & كانت ستكتب & كان سيكتب & غائب (م) \\
\hline yazacak idiniz & كانتا ستكتبان & كانا سيكتبان & (ت) \\
\hline yazacak idiniz & كن سيكتبن & كانوا سيكتبون & (ج) \\
\hline
\end{tabular}

\subsection{Muhtelit (Eclectic) Yöntem:}

Müellifler, Avrupa'da ortaya çıkan yeni yöntemlere ait yabancı dil öğretim kitapları ile birlikte hem klasik Arapça ders kitaplarını hem de Tanzimat Döneminde hazırlanmış diğer eserleri incelemişler ve bu kaynaklardan elde ettikleri bilgileri harmanlayıp meczederek kendilerinin tabiriyle "muhtelit" (eclectic) yöntemde yeni Arapça öğretim kitapları telif etmişlerdir.

\section{Örnek Kitap: Mekteb-i Sultanîye Mahsus Sarf-ı Arabî ve Temrînât ${ }^{148}$ Kitabın Metodik Analizi}

Kitabın iç kapağında şu ifadeden müelliflerde teorik bilgi ve bu bilgilerin pratik olarak kullanılması gerekliliği görüşünün hâkim olduğu ortaya çıkmaktadır:

"Yek diğerine irtibat-1 tâmi olan Mekteb-i Sultanîye mahsus Sarf-ı Arabî ile Temrînât'ın birinci tabları tadilat-1 cüziye ile tevhîd edilmiştir."

Müellif Ahmed Naîm, eserin önsözünde Arap dili öğretimi ile ilgili şu tespitleri yapmaktadır: Daha önce Hacı Mehmet Zihni Efendi’nin el-Muktedab ve el-Muntehab adlı eserine yazdığı takdimde belirtmiş olduğu bazı fikirlerini dile getirmekle başlamıştır. Müellif, Arapçanın Türkler için önemli olduğu ve Fransızca, Almanca gibi bir yabancı dil gibi düşünülerek öğretilmesi gerektiği görüşündedir. Özellikle Arapçanın bu usullerle diğer dillerden daha kolay öğretilip öğrenileceğine inanan müellif, temel ihtiyacın Arapça öğretiminde uygulanacak öğretim

147 İsmail Hâmetî b. Osman, a.g.e., s.136; fiillerin çekim tablosunda aynı usûlü kullanmıştır.

148 Mustafa Cemil - Ahmed Naim, Mekteb-i Sultanîye Mahsus Sarf-ı Arabî ve Temrînât, İstanbul: Mahmud Bey Matbaas1, 1323. 
yöntemleri olduğunu düşünmektedir. Bu yolda Hacı Zihni Efendi’yi kendine örnek alan müellif, onun açtığı yolda ilerlemeyi hedeflemekte ve sonraki kuşakların da bu ilerlemeyi devam ettirmesi fikrini taşımaktadır. Bu eserindeki önsözde belirttiği bu görüşlerine ilaveten, eserle ilgili bazı bilgiler de vermektedir. Mekteb-i Sultani Arapça öğretmenliğine tayin olduğunda, öğrencilere Ders Nazırı Cemil Bey’in Sarf-ı Arabi kitabının okutulmakta olduğunu görmüştür. Bu kitapta sarf kuralları, Arapça öğrenimine yeni başlayan çocukların anlayabileceği nitelikte açık bir üslupla yazılmış, kurallar gayet özet olarak noksansız bir şekilde verilmiştir. Fakat eserin sınıf içinde ögrretimi esnasında talebeye yaptırılacak tatbikat ve temrinat ayrıca hazırlanmamış, bu durum öğretmenlerin inisiyatifine bırakılmıştır. Müellif, kitabın uygulanmasındaki bu boşluğu doldurmak üzere, sarf kurallarını öğretirken, aynı zamanda doğrudan doğruya dilin genel yapısını ve dil becerilerini de öğretmek amacıyla eserini hazırlamıştır.

"Bu yöntemi uygulamak amaciyla, birinci sene öğrencilerine Arapçadan Türkçeye, Türkçeden Arapçaya tercümeler yaptırmaya başladım. Sonuçta; "Temrinat" namıyla bu eser vücuda geldi."149

Temrinat adlı eser bir iki senelik çalışmanın ürünüdür. Kitaptaki en önemli dil öğretim prensibi, sarf kurallarını yeni öğrenmeye başlayan öğrencileri, öğrendikleri kuralları tatbikat ve alıştırmalarla desteklerken, aynı zamanda konuşma ve yazma becerisini de geliştirmeyi hedeflemiş olmasıdır.

Temrinat'ın birinci kısmını düzenlemek için, birinci senenin programı olan salim fiil ve salim isimlerin tam olarak öğrenilmesini sağlayacak derecede bol örnek üretilmiştir. Gerektiği kadar öğrenilen gramer kurallarının yardımıyla rahatça kullanılabilecek isim, fiil ve edatlar için örnek cümleler oluşturulmuştur. İsimlerin çoğulları, fiillerin fail ve mefulleri verilmiştir. Bunların dışında, kitabın muhtelif yerlerine küçük küçük fıkralar, hikayeler alınmıştır. Bu okuma parçalarının amacı, okuma-anlama becerisini geliştirmek ve sözlü etkileşime yönelik olarak ezberlemek olabilir.

Müellif kitabın tertibine, fiil cümlesi ile başlamış, isim cümlesinin gramatik özellikleri “isimler" bahsinde ele almıştır. Bu, okul programına uymak amacıyla yapılmıştır. Ayrıca nahiv kuralları önceki nahiv kitaplarında takip edilen usullerin dişında kendine has bir düzen içinde verilmiştir. Bunun anlamı, Tanzimat Döneminde gelişen yeni öğretim anlayışına uygun olarak Arapçanın öğretiminde sadece sarf-nahiv kurallarının öğretimi değil, aynı zamanda Arap Dili’nin kendisinin öğretilmesinin amaçlanmış olmasıdır.

Müellif, eserini vücuda getirirken, Zihni Efendi'nin fikirlerinden yararlanmanın yanı sıra, Avrupa'da ortaya çıkmış olan "Laryo Eflory" ve "Otto" usullerinden ${ }^{150}$ de istifade ettiğini şöyle ifade etmektedir: ${ }^{151}$

149 Mustafa Cemil - Ahmed Naim, a.g.e., önsöz.

150 Bu alıştırma pratiğine dayanan bir öğretim usulüdür. Bu usulü ilk kez keşfeden “Otto"dur. Yabancı dil öğretiminde en etkili yöntem uygulaması olarak kabul edilmiştir. Bu metot bütün Avrupa dillerine uygulanmış çok etkili ve üst düzey neticeler alınmıştır. Bkz. Salih Vecdi, "Mükâlemat ve Temrinat-1 Arabîye Dersi”, Sebilürreşad, cilt XI, sayı 261, 9 Şevval 1331-29 Ağustos 1329, s. 6.

151 Mustafa Cemil - Ahmed Naim, a.g.e., önsöz. 
"Laryo Eflory" ile "Otto" usüllerinin birden Lisan-1 Arabîyyeye ilk defa olarak acemice tatbîki demek olan bu usül-1 muhtelitin - bu hali iptidaiyesi ve her türlü noksanı ile beraber - pek ziyade muvaffakiyet bahş eylediğini kemal-i itmi'nan ve mufaharetle beyan edersem bundan dolayı haklı görülmeliyim"

Arapça öğretimi konusunda mükemmel tespitler yapan Ahmed Naim'in kitabında dikkat çeken en önemli nokta, kitabın iki yıllık bir uygulama safhasından sonra oluştuğu ve çok saygı duyduğu hocası Hacı Zihni Efendi’nin, Arap Dili öğretimi hakkındaki fikirlerinden ve eserleri el-Müntehab ve el-Müktedab'tan yararlanması ve Avrupalı iki bilim adamının ortaya koydukları öğretim yöntemlerinden istifade etmesidir. Ve bu değerlendirmelerinin bir ürünü olarak, muhtelit (eclectic) bir dil öğretim yöntemi ortaya çıkarmış olmasıdır. Arap Dili öğretiminde bu usulleri ilk defa tatbik eden müellifin bu uygulamadaki başarısı dikkate alınırsa, muhtelit (=eclectic/karma) bir yöntem diye isimlendirdiği bu yöntemi, biz de Ahmed Naim Yöntemi olarak adlandırma cüretini gösterirsek, yanlış yapmış olmayız. Müellif, kendisine has bir tarz diyebileceğimiz bu usulün başarısını, elde ettiği uygulama neticelerini vazederek ispat yoluna gitmektedir. Bu yöntemle Arapça sarf ve yeteri kadar nahiv bilgisini, nazari ve tatbîki olarak öğretirken, yalnız okuma anlama becerisini değil aynı zamanda yazma ve meramını anlatacak kadar konuşma becerilerini de geliştirilebileceğini ortaya koymaktadır. Bu durumda Ahmed Naim'in bu eserini, kendine has olarak geliştirdiği bir yöntemin ders kitabı olarak kabul edebiliriz.

Müellif, yönteminin uygulanma sonuçları hakkında da bilgiler vermektedir. Yalnız haftada iki saat Arapça dersi gören ve daha önce Arapça öğrenmemiş olan, Mekteb-i Sultani’ye yeni başlayan talebelerden birçokları, birinci senenin sonunda bir iki satırlık Türkçe ibareyi Arapçaya, Arapça ibareyi Türkçeye öğretmen yardımı olmaksızın çevirebilmiştir. Her kelimenin gerek kullanım yerleri gerekse çekimi ve i'rabı ile ilgili sorulara gayet doğru cevaplar verebilmişlerdir. İşte bu usulle, birçok kelimenin sarf kurallarını öğrenirken aynı zamanda nahiv kurallarını da teorik ve pratik olarak öğrenmiş oluyorlardı. Netice olarak ulaşılan seviyeyi müellif kendi ifadesiyle şu şekilde belirtmektedir. ${ }^{152}$

“...bu usül dairesinde sarfı bitirinceye kadar nahvin de ekser kavâidini nazarî ve amelî olarak öğrendikten, birçok lugatler ezberledikten mâada 'alâ'l- 'âde yazılmış kütüb ve cerâid-i Arabîyye' den meâl istihrâcına ve oldukça meramlarını ifade ve tahrîre muktedir olabileceklerini isbât ediyorlar."

Öğretim usulünün, 1slah edilip etkili bir hale getirildikten sonra, bütün ilimlerin rahat tahsil edilebileceğine inanan müellif, metotların uygulanma noktasında en önemli faktörün öğretmen olduğunu, öğretmenin daima en etkili ve en kolay usulü bulmak için zihnen uğraş vermesi gerektiğini ve öğretim esnasında edindiği tecrübeleri geliştirmesinin zaruri olduğunu dile getirmektedir. Bu şekilde hareket eden öğretmenin, muhakkak öğretimde en kolay yolu bulabileceğini, belirtmektedir.

152 Mustafa Cemil - Ahmed Naim, a.g.e., önsöz. 
Arapçanın öğretiminde başka usullerinde ihdas edilebileceğini fakat kendisinin bu yöntemi benimseyerek kitabını hazırladığını şu şekilde ifade etmektedir: ${ }^{153}$

"Bu kitab1 ... bir numune-i gayret ve faaliyet olmak ... üzere tab" etmeye cüret ediyorum. Bu lisanı başka usullerle daha ziyade kolaylıkla ta 'lim etmek de varid-i hatır oluyorsa da bir kere başlanmış vesile-i tecarib olmuş olan bu usulden enzar-1 ammeye vaz‘ ettiğim numuneyi itmam ediyor... (ve) başka usule mubaşereti (başlamayı uygun) görmüyorum."

Kitap, Arapçaya yeni başlayanlara yabancı dil öğrenimini ve kitapları sevdirecek tarzda büyük harflerle geniş satır araları bırakılarak büyük puntolara yazılmıştır. Müellifin önsözde belirttiği gibi, ifadeler gereksiz teferruatlardan arındırılmıştır. Haftada iki saatlik bir öğretim süresi dikkate alınarak öğrencilerin zihninde yer edecek, karışıklığa meydan vermeyecek bir ifade usûlü ve daima uygulamaya yönlendiren bir yöntem göze çarpmaktadır.

Kitap, 175 adet "Temrîn” içermektedir. Bu temrînlerde talebeden istenilen çalışma açıkça belirtilmiş ve konuyla ilgili birçok örnek toplanmıştır. Alıştırmalarda ayrıca Arapça-Türkçe veya Türkçe-Arapça tercüme çalışmaları istenmiştir. Arapçadan Türkçeye çeviriler "Tercüme” başlı̆̆g, Türkçeden Arapçaya olanlar ise "Ta 'lîm” başlığıyla verilmiştir. Bazı derslerin alıştırmalarının sonunda, "Lugât" başlığı altında anlamlarıyla beraber kelime listeleri oluşturulmuştur.

\section{Örnek dersin metodik incelenmesi: ${ }^{154}$}

\section{"Fi'l-i teaccüb}

Teaccüb ve istiğrâbı ifade için kullanılan fiildir ki bunun da iki sigâsı vardır:

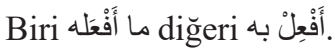

Buradaki (ها (ها) 'ların birincisi zamair-i mansube-i muttasıladan ikincisi zamair-i mecrûradandır. Tasrîfi ( ف ف ( ف ) maddesinde değil âhirine lâhik olan zamirlerde icra ediliyor. Şöyle ki:
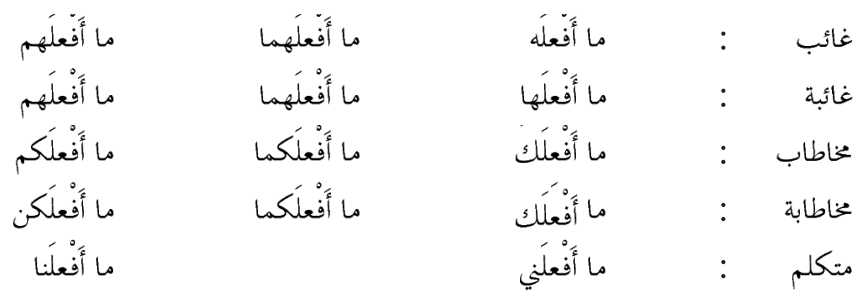

yahud ( أََْعِلْ بِه in yukarıdaki tarzda çekimi yapılır.)

Fi'l-i teaccüb yapmak için zamir yerine bir ism-i zâhir dahi getirilebilir:

= Zleyd ne kadar cahildir, gibi

fi‘l-i teaccüb sigâsı manasında tefâvüt olan ve elvân ve eşkâle müsbet olan sülâsilerden k1yasîdir.

153 Mustafa Cemil - Ahmed Naim, a.g.e., önsöz.

154 Mustafa Cemil - Ahmed Naim, a.g.e., s.108. 


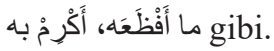

$$
\begin{aligned}
& \text { demek caiz değildir. }
\end{aligned}
$$

Balâdaki şartları câmi' olmayan sülâsilerle mâ fevke'l-sulâsilerden fi' 'l-i teaccüb yapmak için evvelden şiddet ve kesrete delalet eden bir kelimeden teaccüb sigâsı yapılıp ondan sonra asıl matlup olan fiilin mastarı mansub veya mecrur olarak ve bu mastara zamir veya ism-i zahire mudaâf kılınır.

ما أكثرَ إكر امَها، ما أشندّ سو ادَه

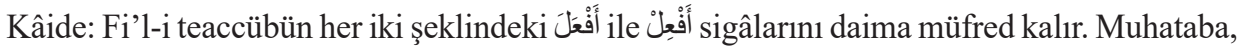
tesniye veya cemi olmaz. Mesela:

denilir. أكرِمو ا بزيد، أَكرِما بزيد denilmez.”

Kaide başlığında iki ayrı açıklama getirilerek nazari açıklama kısmı tamamlanmıştır. Ders konusu olan fi'‘-i teaccüb ile ilgili verilen alıştırmaları inceleyelim: ${ }^{155}$

\section{5}

Zîrdeki mastarlardan fi' 1 -i teaccüb sigâlarını teşkîl ediniz.

$$
\text { علم، جهل، عقل، ذكاء، جسامة، احتجاج، وزن، حمق... }
$$

(toplam 42 adet mastar verilerek teaccüb kalıbı verilmesi istenmiştir.)

\section{6}

عور (tek gözlü olmak)

صلاح (uygun olmak)
شهل (ela gözlü olmak)

تعب (yorulmak)
صفرة (sar1 olmak)

تعجب (şaşırmak)

mastarlarının her iki surette fi'l-i teaccüblerini tasrîf ediniz.

\section{7}

Atîdeki ibarâtta yanlış varsa tashîh ediniz:

ما أحسنه رجلا. بالرجال أحسن. بالمر أة ما أصلح. ما أجمل تللك لدفاتر. أوسخ بهذه الثباب. هذا التلميذ ما أجهل....

“(toplam 15 cümle vardır.)

Bu ve benzeri alıştırmalarda müellif, öğrencinin yapabileceği ihtimal dahilindeki hatalarla ilgili cümleler üretip bu hataları öğrencilerin tespit ve tahsis etmesini istemiştir. Böylece öğrenci, kendi kendine yapabileceği hataları önceden görme ve hatadan uzaklaşma becerisi kazanmış oluyor.

\subsection{Tanzimat Dönemi Dilcileri Tarafından Geliştirilen Yeni Yöntemler}

Türk dilcileri, Arapça öğretimine dair tecrübe ve düşüncelerinin bir sonucu olarak “Arap Dili'ni kolay öğretme" prensibini ön planda tutarak, kendilerine has, özgün eserler meydana getirmişlerdir. Bunlar Tanzimat dönemindeki yeni eğitim anlayışına uygun, Türkler tarafından Arapçanın yabancı dil olarak öğretimi alanında geliştirilen dil öğretim yöntemi çalışmalarıdır.

155 Mustafa Cemil - Ahmed Naim, a.g.e., s.110-111. 


\section{Örnek Kitap 1: Gayetu'l-ereb fî Teallüm-i Lisani'l-Arab ${ }^{156}$ Kitabın Metodik Analizi}

Müellif eserinin önsözünde özetle şunları ifade etmektedir; Arap Diline, memleketimizde daima rağbet gösterilmiştir. Gösterilen bu rağbetin giderek artmasına rağmen uzun yıllar boyunca bu dil, eski usullerle tam olarak öğretilememiştir. Bu dilin öğretimi hususunda birçok kolay usullerin icat edildiğini belirten yazar, okullarda bu yeni usullerle öğretim yapılmasının gerekli olduğu düşüncesindedir. Müellif bütün bunları dikkate alarak gerek okullarda gerekse okul dışında öğrenmek isteyenlere, Arapçayı kısa sürede ve gereği kadar öğreterek öğrencilerin vakit kaybetmelerine sebep olmayacak tarzda yeni bir usulle yazdığı kitabının, Arapça öğretimini kolaylaştıracağı inancını taşımaktadır. Seçmiş olduğu bu usulde, Arapça sarf ve nahvini lüzumu kadar öğretmekle beraber öğrencilerin konuşma ve yazma becerilerini de en kısa zamanda geliştirebileceğini şöyle ifade etmektedir: ${ }^{157}$

“...İhtiyâr ettiğimiz usûlün en büyük fâidesi sarf ve nahvi lüzumu kadar öğretmekle beraber talebelerin tekellüm ve kitabet edebilmelerini pek az bir zamanda te'mîn eylemesidir."

Yeni bir usûl olarak az zamanda Arapça sarf ve nahivden lüzumu kadarını öğretmeyi hedefleyen müellif, bunun yanı sıra Arapça konuşma ve yazmada da talebeye beceri kazandırma iddiasını ortaya atmaktadır. "Yeteri kadar sarf-nahv" ifadesi günümüz dil öğretim yöntemlerinin de benimsediği bir prensiptir. Bu prensibi gözeterek, dilde üretime dayalı konuşma ve yazma becerilerini geliştirmeyi hedeflemesi, yabancı dil öğretim yöntemlerinin ana unsurlarını ve öğretim safhalarını oluşturmaktadır.

Kitabın tasarımında göze çarpan özellikler şunlardır: Kitabın her bir sayfası iki sütuna bölünmüş ve malumat bu iki sütuna sırayla yerleştirilmiştir. Fihristi yoktur. Başlıklar sütunları ortalanmış ve açıklamalara göre daha büyük puntolarla yazılmıştır. Sarf ve nahiv konuları ana ve alt başlıklara bölünerek dersler oluşturulmuştur. İfadeler kısa ve özlü bir şekildedir ve gerektiğinde dipnota alınarak, sayfa altında açıklayıcı bilgiler verilmiştir. Verilen örneklerin yanına Türkçe karşılıkları yazılmıştır. Bazı derslerden sonra "Temrîn” başlığıyla alıştırmalar yer almaktadır, fakat temrînlerde talebeden ne istendiği belli değildir. Sadece kelime ve cümleler Türkçe karşılıklarıyla beraber verilmiştir. ${ }^{158}$

\section{Örnek dersin metodik incelenmesi: ${ }^{159}$}

\section{"Temrîn}

Bugün hararet dünden ziyadedir

Kar yağması yaz mezrû‘âtına zararlıdır

Seher vaktinde kırağı ziyade olur

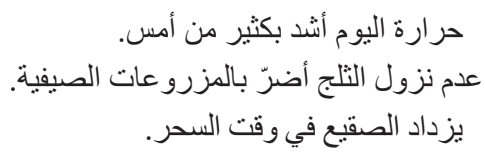

156 Süleyman Tevfik, Gayetu'l-ereb fi Teallüm-i Lisani'l-Arab, İstanbul: el-‘Adl Matbaas1, 1331 (1913).

157 Tevfik, a.g.e., önsöz.

158 Açık, a.g.e., s.188.

159 Tevfik, a.g.e., s.74. 
Bu kitapta takip edilen usulü şöyle tarif edebiliriz: Belirlenen muhtelif ders başlıkları altına ders konusuyla ilgili kelimeler anlamlarıyla beraber sıralanmıştır. Listelenen kelimelerin hemen altında "temrîn” çalışmasına geçilerek, bu kelimeler cümle içinde kullanılmıştır. Örnek cümleler, öğrencinin sınıf içinde ve bireysel çalışmalarında kelimeleri değiştirerek farklı cümleler üretebilmesine olanak verecek şekildedir. Öğrenciye yapıların da öğretildiğini dikkate alarak, temrinlerin yazılı ve sözlü olarak yapabileceğini de düşündügüumüz zaman, bu uygulamaları yeni bir yöntemin izleri olarak değerlendirmemiz mümkün olacaktır. Örnek

${ }^{160}$ :olarak bir dersi ele alalım

\section{"Havâs hamsi (Beş duyu) الحواس الخمس}

\begin{tabular}{|c|c|c|}
\hline & lş. (ج) الأسماع & الذوق :tatmak (ج) الأذواق \\
\hline البصر : görmek (ج) الأبصار & koklamak : الشمّ k & dokunmak, el sürmek: اللمس \\
\hline
\end{tabular}

\section{"Temrîn"}

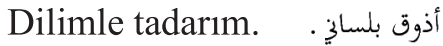
Taâmı neyle tadarsın? بماذا تذوق الطعام

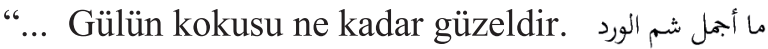

Belirlenen konu başlıklarının, insanın yakın çevresiyle alakalı olan konular olması dikkat çekmektedir. Mesela; zamanlar, insanla ilgili olgular, renkler, hastalıklar, bayramlar, mevsimler, aile fertleri, okul gereçleri, ölçüler, hayvanlar... gibi. Bu bölümden sonra "الكلمات و الجمل المتداولة (İnsanlar arasında kullanımda olan kelime ve cümleler)" ${ }^{161}$ başlığı altında güncel yaşamada kullanımı yaygın olan muhtelif ibare ve cümleler toplanmıştır. Bu cümlelerle yapılan uygulamaların Arapça konuşma becerisini geliştirmeye yönelik olduğu söylenebilir Örnek olarak bir bölümü inceleyelim: ${ }^{162}$

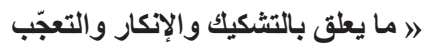

(Şüphe inkâr ve ta'accüb makamında isti‘mal olunan ibarattır.)

Gerçek mi - gerçek midir

Mümkün olur mu - olabilir mi

Acaba gerçek mi söylüyorsunuz

Latife ediyorsunuz

Bunu aslen tasavvur edemiyorum

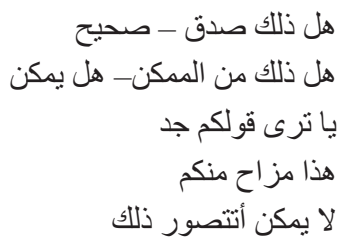

Bu bölümden sonra "Mukâleme"163 başlığı altında 32 adet diyalog verilmiştir. Karşılıklı soru-

160 Tevfik, a.g.e., s.38.

161 Tevfik, a.g.e., s.76-86.

162 Tevfik, a.g.e., s.78.

163 Tevfik, a.g.e., s.87-114. 
cevap tarzında belli bir konu etrafindaki konuşmaları içeren bu diyaloglar, talebenin konuşma becerisini geliştirmeye yöneliktir. Bu diyaloglarda geçen kalıp ifadeler ve yapıların, öğrencilere ezberletildiği düşünüldüğünde konuşma esnasında bu yapıların benzerlerini üretmede zorluk çekmeyecekleri muhakkaktır. Günümüzde uygulanan kulak-dil alışkanlığg yönteminde de, diyaloglar vasıtasıyla dilin en yaygın yapıları öğretilip ezberlenmesi sağlanmakta ve böylece öğrencilere karşılaşacakları yeni durumlarda öğrendikleri ve onlara benzer yapıları üretebilme becerisinin kazandırılması hedeflenmektedir. Müellifin aynı şeyleri hedeflediğini, kitabına aldığg alıştırma ve diyaloglara bakarak söyleyebiliriz. Örnek diyaloğu uygulanan metodu görmek açısından inceleyelim: ${ }^{164}$

\section{(otuzuncu mükâleme) المكالمة الثلاثون (Sarrafile sohbet) مع الصراف (Sarraf ile sohbet)}

يا باش صر اف انا عندي ورقة حو الة عليكم من طرف وكيلكم في ازمير فجئت أسلمها لكم و اقبض المبلغ المحرر فيها.

Sarraf başı İzmir' de bulunan vekiliniz tarafından poliçe vardır. Size teslim edip hâvî olduğu meblağı almak için geldim.

Şimdi poliçedeki meblağa karşı banka kâğıdı veririm.

$$
\text { هل أنا أعطيكم حالا بمذا المبلغ أوراق ميرية مقام النقد. }
$$

Acaba, meblağın bir kısmını altından nakit olarak vermeniz mümkün değil mi?

Pekiyi efendim baș üstüne

حاضر يا سيدي على العين والرأس.

$$
\text { خذوا ورقتين بخمسة آلاف قرش مع عشرين ذهب والبر والباقي فضة ونحاس انظروا هل حسابكم تمام؟ }
$$

İște size beş bin kuruşluk iki tane çek ile yirmi altın bâkisi gümüş ve bakır akçedir. Bakın hesabınız nam midir?

Teraziye çekelim - Tartalım ننظر وزخها - نزفها.

$$
\text { هذا أمر عجيب حيث انه مع نقصائما غير مقصوصة وذنيرها تمام. }
$$

$\mathrm{Bu}$ acayip bir şey! Eksik olmadığı ve zinciri tamam bulunduğu halde eksiktir.

Saf altındandir.

İsterseniz başkasını vereyim.

Beni memnun edersiniz.

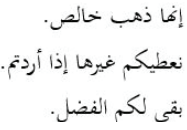

Diyaloglarda karşılıklı konuşmalar alt alta sıralanmıştır. Her cümlenin Türkçesi yanında verilmiştir. Günlük hayatta yaygın olarak kullanılan, ezberlenmesi kolay kısa ifadeler, selamlaşma ve nidâ gibi tabirlere yer verilmiş olması Kulak-Dil Alışkanlığı yöntemine uygundur. Diyalogların akabinde müellif "Muhâvere" başlığı altında soru-cevap tekniğine dayanan bir bölüme yer vermiştir. ${ }^{165} \mathrm{Bu}$ bölümden sonra "emsâl ve mevâ'1z dair"166 adlı bir bölüm yer almaktadır. Burada kullanımı yaygın olan atasözleri ve nasihat niteliğinde meşhur ifadelerden 70 adet toplanmış, Türkçe karşılıklarıyla beraber verilmiştir. Örnek olarak birkaç ifade şöyledir:167

164 Tevfik, a.g.e., s.112-113.

165 Tevfik, a.g.e., s.117.

166 Tevfik, a.g.e., s.119-122.

167 Tevfik, a.g.e., s.122. 
Husud (hased edenler) daima alçaktır

Sözünü icra iden kimse ile çıkışma

Söylemeden evvel düşün

Sehv ve hata insan içindir

$$
\begin{aligned}
& \text { الحسود دائما مغتاظ } \\
& \text { لا تعاند من إذا قال فعل دئل } \\
& \text { تفكر قبل أن تتكلم } \\
& \text { السهو و الخطأ من شأن الإنسان }
\end{aligned}
$$

Daha sonra "Ehâdis-i Şerîfiye Dâir"168 adlı bölüm yer almaktadır. Peygamberimizin selamlaşma, temizlik, namaz, iyilik ve ilim tavsiye eden 50 kadar hadîs alınmış anlamlarıyla beraber verilmiştir. "Eş`âra dâir" 169 isimli bölümde Arap şiirinden bazı örnekler anlamlarıyla beraber verilmiştir. Son bölüm olarak "nesîr tercüme numûneleri" ${ }^{170}$ yer almaktadır. Bu bölümde kısa kısa metinlere yer verilmiş hemen karşılarına metinlerin tercümeleri yapılmıştır. Metinlerin konuları öğrencilere iyilik ve erdemlikler tavsiye eder niteliktedir. Örnek: ${ }^{171}$

"قال أفلاطون - لا تطلب سر عة العمل و أطلب تجويده: فان الناس لا يسألو نلك في كم فرغو و إنما ينظرون إلى إتقانه

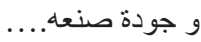

Eflatun demiştir - Bir işi yaparken süratine değil o işin yapılmasına hasr-i ihtimam et. Çünkü halk senden o işin ne kadar vakitte bitirdiğini sormazlar, onun iyi yapılıp yapılmadığını sorarlar..."

\section{Örnek Kitap 2: Temrînli ve I' rablı Lisan-ı Arabî Sarf Kısmı, ${ }^{172}$ Kitabın Metodik Analizi}

Müellif kitabı yazma konusundaki gayesini dile getirirken, Arapçayı bir yabancı dil olarak kolay öğrenilir hale getirmek amacını güderek yazdığını dile getirmektedir. Bu da bize kitabın, Arapçanın kolay öğretimini sağlamak gayesine yönelik bir yöntem arayışıyla yazıldığını göstermektedir. Müellifin bu konudaki görüşleri özetle şöyledir: Öğrenilmesi zaruri olan Arapçay1 öğretmek üzere Türkçe olarak hazırlanmış gramer kitaplarının çoğu yetersizdir. Arapçanın sarf ve nahiv kurallarını bir arada öğretirken dilin kendisini de öğrenmeyi kolaylaştıracak kolay ve anlaşılır ifadelere sahip bir usul üzere kitabını yazdığını ifade etmektedir.

Mekteb-i Sultani'nin programına uygun olarak gerekli alıştırmaları ve tahlilleri içeren kitabını hazırlarken, hocası Hacı Zihni Efendi'nin hazırladığı el-Muntahab ve el-Muktadab'1 kendisine mehaz edinmiştir. Müellifin önsözde yer alan ifadesi şöyledir:

“...evlad-1 Arabdan bir talebe mu'tel olan bir fiilin aslını düşünmeyerek mazisini muzarisini emrini bulabilirse de bir Türk, bir Rum ve bir Ermeni bunun efâil-i sahihadan başka bir şekil alacağını kavâid-i mezkureyi öğrenmeden bilemez. Maamafi yalnız kavâid öğrenmekle lisan tahsîl olamayacağı meydanda olduğundan kavâid-i mezkureye dair temrînât-1 kâfiye dahi ilave olunmuştur. Ümit ederim ki bu kitabın kavâid ve temrînâtını layıkıyla tahsîl eden bir talebe bu lisanı hissemend olur. Herhalde bir kitap ne kadar mükemmel olursa olsun lisanın

168 Tevfik, a.g.e., s.122-125.

169 Tevfik, a.g.e., s.125-128.

170 Tevfik, a.g.e., s.128-131.

171 Tevfik, a.g.e., s.129.

172 Hanbelizâde Mehmed Şakir, Temrînli ve Í rablı Lisan-ı Arabî Sarf Klsmı, İstanbul: Reşadiye Matbaası, $1327 / 1329$. 
teshîl-i tahsîlinde birinci derecede zî medhâl olan şey muallimin takîb edeceği tarz-1 tedrîs ile tatkibatın kesretidir." 173

Müellifin yukarıdaki açıklamalarından, Türkçe kullanılarak yazılan Arapça gramer kitaplarının tam bir yöntem uygulayabilmek için yeterli olmadığını, bu tür gramer kitaplarının, mutlaka alıştırma ve tercüme çalışmalarıyla desteklenmesinin gerekliliği anlaşılmaktadır. Ayrıca müellifin, teorik bilgilerin verilmesinin dil öğretiminde tek başına yeterli olmadığı, dile ait bilgilerin uygulama safhasına geçirilmesi ve öğretmen tarafından tatbik edilecek bir öğretim yöntemiyle üretime yönelik becerilerin geliştirilmesi fikrinde olduğu ortaya çıkmaktadır. Bu konuda yazarın, özellikle döneminde Arapça öğretiminin kolaylaştırılması için büyük çalışmalar geliştirmiş olan Zihni Efendi'nin, fikir ve eserlerinden yararlanması, mevcut yöntem çalışmalarını daha da geliştirme arzu ve gayretinde olduğunu göstermektedir.

Kitapta sarf-i Arabî konusunda 120 ders bulunmaktadır. Dersler numaralandırılmamıştır fakat, kitabın sonunda konu fihrist mevcuttur. Ayrıca kitapta "temrin" başlı̆̆ıyla oluşturulan alıştırmalar bulunmaktadır. Temrînler kendi içerisinde numaralandırılmıştır. Fihristte bu alıştırmalara yer verilmemiştir. 120 Ders için toplam 56 Temrîn oluşturulmuştur. Müellif ders konularını açıklarken ihtiyaç duyduğu yerlerde sayfa altında dipnotlar oluşturarak konuyla ilgili daha geniş bilgi vermiştir.

\section{Örnek dersin metodik incelenmesi: ${ }^{174}$}

\section{"Fi'l-i Teaccüb}

Fi‘l-i teaccüb inşâ-i teaccübe mevzu bir fiildir. Teaccübün iki sigâsı vardır.

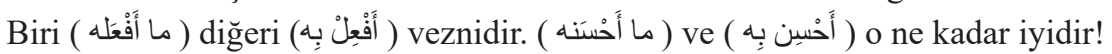

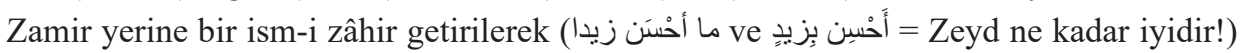
denilir.

Fi'l-i teaccübden zamirsiz tesniye teşkil olunmadığı gibi cem dahi teşkil olunmaz. Fi'l-i teaccüb zamir ile şu surette tasrîf olunur :
(14 sigâ tamamlanır)

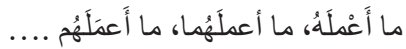
(14 sigâ tamamlanır)

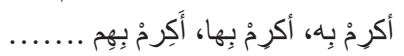

Fi'l-i teaccüb ism-i tafdîl gibi manasında tefâvüt bulunan ve elvân ve 'uyûb ve eşkâle delâlet etmeyen sülâsilerden kiyasîdir. (ما أموانَّه : ما أعَّاه : ne kadar ölüdür kadar kördür) sigâları ise söz olarak varid olmuştur.

Fevke's-sülâsiden veya elvân ve 'uyûb ve eşkâle delalet eden kelimâttan fiil-i te'accüb binâ etmek lazım gelirse ism-i tafdîlde olduğu gibi tafdîle delalet eden أثثر ge أثدّ gibi sigâlara tevsîl olunur.

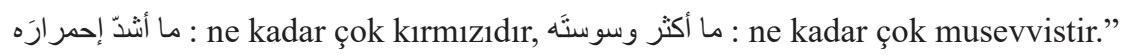

Daha sonra "Tenbih" 175 başlı̆̆ı altında konuyla ilgili dikkat edilmesi gereken bazı noktalara

173 Mehmed Şakir, a.g.e., s.3.

174 Mehmed Şakir, a.g.e., s.99.

175 Mehmed Şakir, a.g.e., s.100-101. 
açıklamalar getirilmektedir. Müellifin üslubunda, sade ve akıcı bir dil göze çarpmaktadır. Kısa malumat ve çok örnekler getirilmektedir. Ayrıca daha önceki bilgilerle karşılaştırmalar yapılarak, talebelerin zihnindeki bilgiler arasında bağ kurulmaktadır. Bu da öğrenilen malumatın hatırda tutulmasına ve öğrenimin pekiştirilmesine yardımcı olmasına yönelik bir yöntemdir.

Fi'l-i teaccüb konusunda getirilen "Temrîn-37” inceleyelim: ${ }^{176}$

\section{"Temrîn 37}

Zîrdeki cümleleri Türkçe'ye tercüme ediniz:

$$
\text { ما أَلطَف زمانَ الربيع، أحسِنْ بتربيةِ زيدٍ، أنْعِمِ بهذا الأمير، ما أسنعَدني برؤياك، ما أجملَ مشاهدةً البدر ....... }
$$

(Toplam 20 civarında cümle vardır.)

Zîrdeki mastarlardan fi' 1 -i teaccüb sigâları binâ ediniz :

$$
\text { العلم، الجهل، الفهم، العقل، الجبانة، المسكنة، الفقر، الجسامة، التجربة، التباعد، الثجاعة، الاجتماع ”..... }
$$

Temrînlerde konunun yapısıyla uygun olacak şekilde bazen Türkçeden Arapçaya, bazen Arapçadan Türkçeye tercüme istenmiştir. Sarf konusu ile ilgili vezinlerin üretilmesi için çoğunlukla mastar kalıpları verilmiştir.

\section{SONUÇ}

Tanzimat'ın ilanından sonra açılan yeni okullarda Arapça öğretimi, medreselerdeki Arapça öğretiminden farklı bir yaklaşımla ele alınmıştır. Bu yeni yaklaşımın en önemli özelliği, yeni okullarda Arapçanın yabancı dil olarak kabul edilmesi ve bir yabancı dil olarak öğretiminin ele alınmasıdır. Arapça öğretimiyle meşgul olan dilciler benimsenen bu esas üzerine, öğretim kaynaklarının hazırlanmasında bazı yeniliklere gitmişlerdir. Bu yeniliklerin en önemlisi, Arapçanın ideal öğretiminin belli bir metoda bağlı olarak mümkün olacağı yaklaşımıdır. $\mathrm{Bu}$ amaçla, müellifler kitaplarını klasik tarzın dışında farklı ve yeni metotların kurallarına göre tertip ve düzenlemeler yaparak hazırlamaya başlamışlardır. Bunun ilk adımı; yeni tarz kitapların klasik usuldeki şerh ve haşiyelerle yazım usulünden arındırılmasıdır. Yeni tarz kitapların hazırlanmasında ikinci ve en önemli özellik müelliflerin yeni metot arayışlarıdır. Arapçayı en kolay usullerle öğretme prensibine dayanan bu yeni metot arayışında müellifler kendi gayretlerinin yanı sıra, Avrupa ülkelerinde ortaya çıkan yeni metotları da takip etmişler ve onlardan istifade etmişılerdir. Bazı dilciler kendileri yeni bir metot ortaya koyarken, bazıları Avrupa'da ortaya çıkan yöntemlerin prensiplerine uygun kitaplar hazırlamış, bazıları da Avrupa'da ortaya çıkan yöntemlerle kendi fikir ve yaklaşımları ile kaynaştırarak yeni bir yöntem ortaya koymaya çalışmışlardır. Bu çalışmalar Maarif Nezareti, Askeri kurumlar, özel okullar ve vakıflar tarafından desteklenmiş ve hazırlanan kaynaklar bu kurumlara bağlı okullarda uygulanmıştır. Böylece dilciler, hazırladıkları kitaplarda ortaya koydukları yöntemlerin sonuçlarını gözlemleme fırsatı bulmuşlardır. Sonuçta; Arapçanın, Osmanlı Devleti sınırları içinde bir yabancı dil olarak öğretimi konusunda özgün öğretim yöntemleri ortaya koymuşlar

176 Mehmed Şakir, a.g.e., s.101-102. 
ve bunları geliştirmişlerdir. Bunlar arasında; Mehmed Zihni Efendi, Hacı İbrahim Efendi, Ahmed Naim gibi bu alana emek vermiş, Arapça ve Arapçanın yabancı dil olarak öğretimi alanında uzmanlaşmış alimler vardır. Arapçanın kolay ve etkili öğretimi için fikir ortaya koymuş, düşüncelerini prensip haline getirmiş ve bir yöntem çerçevesinde kitaba dönüştürerek Arapça öğretiminde uygulamış bu alimlerimizin sahip oldukları özelliklerinin arasına "yabancı dil öğretim yöntemcisi”" payesinin de eklenmesi gereklidir. Mesela; Ahmed Naim, Mekteb-i Sultanîye Mahsus Sarf-ı Arabî ve Temrînât isimli eserinde uyguladığı yöntemin en iyisi olduğunu ve Arapçayı en kolay ve etkili usulle öğreteceğini açıkça iddia etmektedir. Hacı İbrahim Efendi, "Dâru't-Talim” adını verdiği özel okulda uyguladığı yöntemle, üst düzey Arapça öğretimi gerçekleştirmiş ve öğrenciler Padişah huzurda imtihana tabi tutularak başarılarını ispatlamışlardır. Hacı Mehmed Zihni Efendi’nin “Arapçayı bana kolay geldiği gibi öğretmeyi amaçladım" diyerek hazırlamış olduğu el-Muntehab ve el-Muktadab isimli kitaplar, günümüzde dahi kullanılan Arapça öğretim alanının en güzel numuneleri olarak Arapça öğretimi alanında seçkin bir elde etmişlerdir.

Tanzimat Dönemi’nde genelde eğitim alanında özelde Arapça öğretimiyle ilgili söylenebilecek en önemli sorun, ortaya konulan bu yenilikçi hamlelerin hayata geçirilip yaygınlaştırılamamasıdır. Bunun sebebi de yeni öğretim yöntemlerine hâkim yetişmiş öğretmen sayısının yeterli olmamasıdır. Bu amaçla açılan Daru'l-muallimin söz konusu ihtiyacı karşılamaktan çok uzaktı. İmparatorluk sathındaki okullarda, yetkin öğretmen eksikliğinden kaynaklanan eğitimde kalite sorunu yaşanmaktaydı.

Sonuç olarak; Tanzimat'tan Cumhuriyet'e kadar olan dönemde, Arapçanın öğretimi konusunda yapılan ateşli tartışmalar ve ortaya atılan yeni fikirler lafta kalmamıştır. Gerek batı dünyasında oraya çıkan yabancı dil öğretim usülleri gerekse Türk dilcilerin özgün olarak ortaya koyduğu Arapça öğretim yaklaşımları, birçok değerli alim tarafından hazırlanan öğretim kitaplarına “Arapça öğretim yöntemi” olarak yansımış ve birçok okulda uygulanmıştır. Bu yenilikçi yaklaşımı benimseyen birçok Arapça uzmanı, yetişmiş ve Arapçanın yeni usullerle daha kolay ve etkili şekilde öğretilebileceğini ispatlamışlardır. Tanzimat Dönemi'nde yapılan bu çalışmaların Arapçanın öğretimi alanına olumlu katkılar yaptığı da yadsınamaz bir gerçektir.

Hakem Değerlendirmesi: Dış bağımsız.

Çıkar Çatışması: Yazar çıkar çatışması bildirmemiştir.

Finansal Destek: Yazar bu çalışma için finansal destek almadığını beyan etmiş̧ir.

Peer-review: Externally peer-reviewed.

Conflict of Interest: The author has no conflict of interest to declare.

Grant Support: The author declared that this study has received no financial support.

\section{Kaynakça/References}

Açık, Kerim, "Tanzimat’tan Cumhuriyete Arapça Öğretimi (Kaynaklar ve Yöntemler)", Yayımlanmamış

Doktora Tezi, Marmara Üniversitesi Sosyal Bilimler Enstitüsü, İstanbul 2002. 
Ahmed Cevdet Hocazâde, Arapça Yeni Sarf ve Nahiv (İkinci Kısım), İstanbul: Mekteb-i Harbiye Matbaası, 1323.

Akgündüz, Hasan, “Teşkilat ve İşleyiş Bakımından Osmanlı Medrese Sistemi”, Türk Dünyası Araştırmaları, 1992, sy. 80 .

Akgündüz, Hasan, Klasik Dönem Osmanlı Medrese Sistemi: Amaç-Yapı-İşleyiş, İstanbul: Ulusal Yayınları, 1997.

Aksoy, Özgönül, Osmanlı Devri Sıbyan Mektepleri Üzerine Bir İnceleme, İstanbul: İstanbul Teknik Üniversitesi Mimarlık Fakültesi, 1968.

Akyüz, Yahya, Türkiye Ĕgitim Tarihi, İstanbul 1994.

Arslan, A. Turan, “Hacı İbrahim Efendi ve Daru’t-Talim Müessesi”, İlmi Araştırmalar, sy. 7, İstanbul 1999.

Arslan, A. Turan, "XVI. Osmanlı İlmi Hayatına Genel Bir Bakış”, Osmanlı VIII, Ed. Güler Ercan, Ankara: Yeni Türkiye Yayınları, 1999.

Arslan, A. Turan, Son Devir Osmanlı Alimlerinden Mehmed Zihni Efendi, İstanbul: Marmara Üniversitesi İlahiyat Fakültesi Vakfi, 1999.

Atay, Hüseyin, Osmanlılarda Yüksek Din Eğitimi, İstanbul: Dergâh Yayınları, 1983.

Ayni, Mehmet Ali, Darulfunun Tarihi, İstanbul: İstanbul Darulfünunu, 1927.

Aytekin, Halil, Ittihat ve Terakki Dönemi Eğitim Yönetimi, Ankara: Gazi Üniversitesi Eğitim Fakültesi Yayınlar1, 1991.

Baykal, İsmail H., Enderun Mektebi Tarihi, İstanbul, t.y.

Bilim, Cahit Yalçın, Tanzimat Devrinde Türk Eğitiminde Çăgdaşlaşma 1839-1876, Eskişehir: Anadolu Üniversitesi Yayınları, 1984.

Bilsel, Cemil, İstanbul Üniversitesi Tarihi, İstanbul: İstanbul Üniversitesi Yayınları, 1943.

Binbaşığlu, Cavit, Türkiye 'de Ĕ̆itim Bilimleri Tarihi Üzerinde Bir Araştırma: Öğretmen Yetiştirme Açısından, Ankara: Milli Eğitim Bakanlığı Yayınları, 1981.

Çelebi Ahmed, İslâm 'da Ĕgitim Öğretim Tarihi, çev. Ali Yardım, İstanbul: Damla Yay., 1998.

Ergin, Osman, Türkiye Maarif Tarihi (II. Basım), İstanbul: Eser Neşriyat, 1994.

Ergün, Mustafa, II. Meşrutiyet Devrinde Eğitim Hareketleri (1908-1914), Ankara: Ocak Yayınları, 1996.

Galata Sultanîsi Edebiyat Muallimi Ali Suad, el-Hedaya Dergisi kurucusu ve el-Hilal el-Osmani gazetesi sahibi Abdülaziz Caviş, İstanbul Sultanîde Arapça Muallimi Edhemzade Muhammed Kemaleddin, Ta'limu'lLugati'l-Arabîye a 'lâ Tarîkat-ı Berlitz, İstanbul: Mahmud Bey Matbaası, 1331.

Gaspıralı, İsmail, Eğitim Yazıları, Haz.: Yavuz Akpınar, İstanbul: Ötüken Neşriyat, 2017.

Halaçoğlu, Yusuf, XIV-XVII. Yüzyıllarda Devlet Teşkilatı ve Sosyal Yapı, Ankara 1995.

Hanbelizâde Mehmed Şakir, Temrînli ve Írablı Lisan-ı Arabî Sarf Kısmı, İstanbul: Reşadiye Matbaası, $1327 / 1329$. İbrahim Şemseddin, Nahv-i Arabî, İstanbul: Arif Efendi Matbaası 1317.

İhsanoğlu, Ekmeleddin. “Osmanlı Eğitim ve Bilim Kurumları” Osmanlı Devleti ve Medeniyeti Tarihi, Ed. Ekmeleddin İhsanoğlu, c. II, İstanbul: İslam Tarihi, Sanat ve Kültür Araştırma Merkezi (IRCICA) 1998, s.223-359.

İsmail Hâmetî b. Osman. Usûl Tedrîs-i Arabî (Mösyö (An) K Usûlünden müktebestir), İstanbul: Necm-i İstikbal Matbaas1, 1329.

Karaaslan, Nasuhi Ünal. “L’enseignement En Language Arabe Cehez Les Tures Ottomans Jusgu'aux”, Basılmamış Doktora Tezi, Paris: Tanzimat Üniversite De Paris-Sarbonne, 1976.

Kazıcı, Ziya. Osmanlı'da Ĕ̆itim-Öğretim, İstanbul: Bilge Yayınları, 2004. 
Koçer, H. Ali. Türkiye Modern Eğitiminin Doğuşu ve Gelişimi, İstanbul 1991.

Kodaman, Bayram \& Abdullah Saydam. "Tanzimat Devri Eğitim Sistemi”, 150. Yıldönümü Uluslararası Sempozyum Bildiriler, Ankara: Milli Kütüphane, 1991.

Kodaman, Bayram. Abdülhamit Devri Ĕ̆itim Sistemi, Ankara 1991.

Koray, Enver. Türkiye’nin Çă̆daşlaşma Sürecinde Tanzimat, İstanbul: Marmara Üniversitesi Fen Edebiyat Fakültesi Yayınları, 1991.

Maârif-i Umûmiye Nizamnâmesi. 1869, 79-128. maddeler.

Mahmud Cevad, İbn el-Şeyh Nafi. Maarif-i Umumiye Nezareti Teşkilatı ve İcraatı, İstanbul: Matbaa-1 Amire, 1338.

Makdisi, George. Ortaçă̆’da Yüksek Öğretim -İslâm Dünyası ve Hıristiyan Batı-. İstanbul: Gelenek Yayıncılık, 2004.

Mehmed Zihni Efendi. el-Muntehab ve'l-Muktedap fi Kavadi's-Sarfve'n-Nahv, İstanbul: Şireket-i Mürettibye Matbaas1, 1303.

Mehmedoğlu, Yurdagül. Tanzimat Sonrasında Okullarda Din Eğitimi (1838-1920), İstanbul: Marmara Üniversitesi İlahiyat Fakültesi Vakfı Yayınları, 2001.

Mektebi Sultani’nin Ellinci Sene-i Devriyesi Münasebetiyle, İstanbul: Mabaa-i Amire 1919.

Mustafa Cemil - Ahmed Naim. Mekteb-i Sultanîye Mahsus Sarf-ı Arabî ve Temrînât, İstanbul: Mahmud Bey Matbaas1, 1323.

Özcan, Abdülkadir. “Tanzimat Döneminde Öğretmen Yetiştirme Meselesi”, 150. Yıldönümü Uluslararası Sempozyum Bildiriler, Ankara: Milli Kütüphane, 1991.

Salih, Vecdi. "Mükâlemat ve Temrinat-1 Arabîye Dersi”, Sebilürreşad, c. XI, sy. 261, 9 Şevval 1331-29 Ağustos 1329.

Sarıkaya, Yaşar. Medreseler ve Modernleşme, İstanbul: İz Yayıncılık, 1997.

Şanal, Mustafa. “Osmanlı Devleti’nde Medreselerde Ders Programları, Öğretim Metodu, Ölçme ve Değerlendirme: Öğretimde İhtisaslaşma Bakımından Genel Bir Bakış”, Sosyal Bilimler Enstitüsü Dergisi, c. I (14), 2003.

Şeşen, Ramazan. “Osmanlılar Döneminde Arap Dili Ve Edebiyatı Öğretimi”, Studies On Turkish-Arap Relations, İstanbul: Türk Arap İlişkilerini İnceleme Vakfı Yayını, 1986.

Şişman, Adnan. Galatasaray Mekteb-i Sulatnisi’nin Kuruluşu ve İlk Öğretim Yılları (1868-1871), İstanbul: Edebiyat Fakültesi Matbaas1, 1989.

Tekeli, İlhan ve Selim İlkin. Osmanlı Imparatorluğu'nda Eğitim ve Bilgi Üretim Sisteminin Oluşumu ve Dönüşümü, Ankara: Türk Tarih Kurumu, 1993.

Tevfik, Süleyman. Gayetu'l-ereb fi Teallüm-i Lisani'l-Arab, İstanbul: el-‘Adl Matbaas1, 1331(1913).

Türkiye Diyanet Vakfi İslam Ansiklopedisi, Öztürk, Cemil. İstanbul: Türkiye Diyanet Vakfı Yayınları, c. VIII, 1993, "Darulmuallimin" maddesi.

Türkiye Diyanet Vakfi İslam Ansiklopedisi. es-Sakkâr, Sâmî. "Muîd” maddesi, https://islamansiklopedisi.org. tr/muid--medrese (13.06.2020).

Ulusoy, Ahmed. "Kuruluşundan 17. Yüzyıla Kadar Osmanlı Medreselerinde Eğitim-Öğretim Faaliyetleri”, Yayımlanmamış Yüksek Lisans Tezi, Konya: Selçuk Üniversitesi Sosyal Bilimler Enstitüsü, 2007.

Unat, F. Reşit. Türkiye’de Eğitim Sisteminin Gelişimine Tarihi Bir Bakış, Ankara: Milli Eğitim Bakanlı̆̆ı, 1964. 
Uzunçarşı1l, İ. Hakkı. Osmanlı Devleti'nin İlmiye Teşkilatı, Ankara 1988.

Ülkütaşır, M. Şakir. “Sıbyan Mektepleri”, Türk Kültürü, sy. 33/Temmuz, Ankara 1965.

Yaltkaya, Şerafettin. “Tanzimattan Evvel ve Sonra Medreseler”, Tanzimat I: Yüzüncü Yıldönümü Münasebetiyle, Ankara: Maarif Vekaleti, 1940.

Yazıc1, Nesimi. "II. Meşrutiyette Din Görevlisi Yetiştiren Kurumlar Üzerine Bazı Gözlemler”, M.E.B. Din Öğretimi Dergisi, sy. 36/ Eylül-Ekim, Ankara 1992.

Yücel, Hasan Ali. Türkiye’de Orta Öğretim, Ankara: Kültür Bakanlığı, 1994. 
